\title{
STUDY ONTHE SUSTAINABLE INDICATORS AND RESEARCH METHODOLOGY IN THE CONTEXT OF THE SUSTAINABLE DEVELOPMENT RESERVE OF TUPÉ, AMAZONAS - BRAZIL
}

\author{
Duarcides Ferreira Mariosa ${ }^{1}$; Samuel Carvalho De Benedicto ${ }^{2}$; Cibele Roberta Sugahara ${ }^{3}$
}

ABSTRACT: The present study goal is to propose sustainability indicators based on environmental, spatial, cultural, social and economic dimensions and to validate a research methodology in the context of the Sustainable Development Reserves. The main reason to the development of this research is the necessity of establishing sustainable indicators to comprehend the reasons behind populational dislocation in communities located in Sustainable Development Reserves, considering the need of guided actions to a more sustainable development of these populations. The methodological research proposed is "qualitative, longitudinal and ecological study", deploying techniques of straight observation, and applying semi-structured questionnaires between the years of 2009, 2010, 2013, 2014, and 2018. The indicators and the methodology were applied in two riverine communities in the Sustainable Development Reserve of Tupé, located in Manaus, Amazonas, Brazil. This particular methodology can be used to identify belonging sings, population dislocations reasons, critical point solution, and elaboration of public policies. Allows to partially analyze the sustainable indicators within a certain period or the evolving of the sustainable index throughout the time. The given methodology has showed that, during the study period, an emptying of housing units occurred in the order of $23,5 \%$ in São João Community, on the other hand, there was an increasing of $24 \%$ in Agrovila Community. The work and income conditions, and also the deterioration of staying conditions has an impact on the desire of populational dislocation. However, the sociocultural bonds, psychosocial connection, and historical biographies linked to the place (belonging sings), have an important role in the individual decision of leaving or staying.

KEYWORDS: research methods; sustainable indicators; sustainability; belonging sings; sustainable development reserve.

RESUMO: Este estudo tem como objetivo propor indicadores de sustentabilidade pautados nas dimensões ambiental, espacial, cultural, social e econômica e validar uma metodologia de pesquisa no contexto de Reserva de Desenvolvimento Sustentável. A principal motivação para o desenvolvimento da pesquisa é a necessidade de estabelecimento de indicadores de sustentabilidade para compreender os motivos de deslocamento populacional em comunidades de Reserva de Desenvolvimento Sustentável, considerando-se a necessidade de ações orientadas ao desenvolvimento mais sustentável dessas populações. A metodologia de pesquisa proposta é do tipo "qualitativa, longitudinal e estudo ecológico", utilizando técnicas de observação direta e aplicação de questionário semiestruturado entre os anos de 2009, 2010, 2013, 2014 e 2018. Os indicadores e a metodologia foram aplicados em duas comunidades ribeirinhas da Reserva de Desenvolvimento Sustentável do Tupé, localizadas em Manaus, Amazonas, Brasil. Essa metodologia pode ser utilizada para a identificação de sinais de pertença, motivação do deslocamento populacional, solução de pontos críticos e formulação de Políticas Públicas. Permite analisar os indicadores de

\begin{abstract}
sustentabilidade parcialmente num determinado período ou na verificação da evolução do índice de sustentabilidade ao longo do tempo. A metodologia proposta permitiu evidenciar que, no período estudado, houve um esvaziamento das unidades de habitação na ordem de $23,5 \%$ na Comunidade São João do Tupé e um crescimento de $24 \%$ na Comunidade Agrovila. As condições de trabalho e renda e a deterioração das condições de permanência impactam no desejo de deslocamento populacional. Entretanto, os laços socioculturais, vínculos psicossociais e biografias historicamente entrelaçadas com o lugar (sinais de pertencimento), pesam nas decisões individuais de partir ou ficar.
\end{abstract}

PALAVRAS-Chave: métodos de pesquisa; indicadores de sustentabilidade; sustentabilidade; sinais de pertença; reserva de desenvolvimento sustentável.

RESUMEN: Este estudio tiene como objetivo proponer indicadores de sostenibilidad pautados en las dimensiones ambiental, espacial, cultural, social y económica y validar una metodología de investigación en el contexto de Reserva de Desarrollo Sostenible. La principal motivación para el desarrollo de la investigación es la necesidad de establecer indicadores de sostenibilidad para comprender los motivos de desplazamiento poblacional en comunidades de Reserva de Desarrollo Sostenible, considerando la necesidad de acciones orientadas al desarrollo más sostenible de esas poblaciones. La metodología de investigación propuesta es del tipo "cualitativa, longitudinal y estudio ecológico", utilizando técnicas de observación directa y aplicación de cuestionario semiestructurado entre los años 2009, 2010, 2013, 2014 y 2018. Los indicadores y la metodología se aplicaron en dos comunidades ribereñas de la Reserva de Desarrollo Sostenible del Tupé, ubicadas en Manaus, Amazonas, Brasil. Esta metodología puede ser utilizada para la identificación de señales de pertenencia, motivación del desplazamiento poblacional, solución de puntos críticos y formulación de Políticas Públicas. Permite analizar los indicadores de sostenibilidad parcialmente en un determinado período o en la verificación de la evolución del índice de sostenibilidad a lo largo del tiempo. La metodología propuesta permitió evidenciar que en el período estudiado hubo un vaciamiento de las unidades de vivienda en el orden del 23,5\% en la Comunidad São João do Tupé y un crecimiento del $24 \%$ en la Comunidad Agrovila. Las condiciones de trabajo y renta y el deterioro de las condiciones de permanencia impactan en el deseo de desplazamiento poblacional. Sin embargo, los vínculos socioculturales, vínculos psicosociales y biografías históricamente entrelazados con el lugar (signos de pertenencia), pesan en las decisiones individuales de partir 0 quedarse

PALABRAS-ClaVE: métodos de investigación; indicadores de sostenibilidad; sostenibilidad; signos de pertenencia; reserva de desarrollo sostenible.

Duarcides Ferreira Mariosa, Doctor in Sociology at State University of Campinas - UNICAMP, Brazil. Integrated Researcher at OBSERVARE Research Center of the Autonomous University of Lisbon, Portugal. E-mail: dmariosa@autonoma.pt

2 Samuel Carvalho De Benedicto, Doctor in Administration at Federal University of Lavras (UFLA), Brazil. Professor at Catholic University of Campinas (PUC-Campinas), Center for Economics and Administration, Postgraduate Program in Sustainability, Campinas - SP, Brazil. E-mail: samuel.benedicto@ puc-campinas.edu.br

3 Cibele Roberta Sugahara, Doctor in Information Science at University of São Paulo - USP, Brazil. Professor at Catholic University of Campinas (PUC-Campinas), Center for Economics and Administration, Postgraduate Program in Sustainability, Campinas - SP, Brazil. E-mail: cibelesu@puc-campinas.edu.br 


\section{INTRODUCTION}

A new paradigm of development has been consolidating in this beginning of millennium: the sustainable development. It is a conception about the growth measure of a society or a territory that considers not only wealth generation (economic dimension), but also the conditions of appropriation of this generated wealth, substantiated in the planning and distribution of cultural values of each society (cultural dimension), increasing of the population's quality of life (social dimension), and the equilibrium relation between society and nature (environmental dimension). (Scandar Neto, 2006).

The efforts used until now to comprehend the growth measure and the stage where a society or territory is come, invariably, to a proposition of a set of indicators needed to this purpose known as Sustainable Development Indicators - SDI (Fang, Heijungs \& De Snoo, 20I4).)

The literature shows that, after the 1990 decade, many propositions related to the building of sustainable development indicators came up. The scientific literature lists that a variety of indicators has already been proposed with applications in different places and situations (Ridoutt \& Pfister, 20I3). According to Carvalho and Sposto (2012) sustainability indicatorswere first used in the nations scope, as an answer to the Agenda 2I. After that, many indicators levels were established: sustainability indicators sustained by the Bellagio Principles (1996) reviewed and updated at the Bellagio Sustainability Assessment and Measurement Principles (STAMP) in 2009 (IISD) International Institute for the Sustainable Development, national indicators (OECD, UN, World Bank, UN CSD); sustainability sectoral indicators of civil construction (CIRIA, CRISP); organizational sustainability indicators (Global Reporting Initiative Guidelines); buildings and projects indicators (LEED, BREEAM, GBC); among others.

Nonetheless, there aren't many studies that discuss and shows sustainability indicators able to guide the work of researchers in Sustainable Development Reserves (SDR). GRI indicators, for instance, can't be used outside the organizational environment, because, according to Pintérd et al. (20I2), by providing a list of environmental, economic, and social performance indicators, the choice between criteria is not enough to implement and reflect in a systemic way the inner values to the sustainable development in environments supposed to arrange other dimensions, as the communities located in sustainable development areas, target of this study.

Therefore, this research question is: what are the sustainability indicators applicable to study the belonging of people living in Sustainable Development Reserves and what is the methodology that can be used for this purpose?

The study's goal is to propose sustainability indicators based on environmental, spatial, cultural and economic dimensions and to apply a research methodology in the context of Sustainable Development Reserves.

The target of this study was to build a methodology based on a set of sustainable development indicators applicable to communities located in Sustainable Development Reserves. The research presents a methodological contribution supported by a proposition of sustainability indicators. As a result, it is presented a relation of variables related to indicators that allows identification of the reasons behind belonging signs (population dislocation) in communities located in Sustainable Development Reserves. The study presents subsidies to interventions and modifications in the reality in search to a sustainable development.

The present study adopts the synthetic indicators approach to cover the dimensions, and their respective indicators and variables based on the Scandar Neto study (2006).

The target of this study was to build a methodology based on a set of sustainable development indicators applicable to communities located in Sustainable Development Reserves. In order to reach this goal, the present study is divided in two distinct and complementary parts. In the first part, based on the sustainable dimensions proposed by Sachs (2008), it was sought the building of some indicators and variables that can be used to develop studies for various purposes in a Sustainable Development Reserve. In the second part, the target was to validate some indicators and variables listed by the application and validation of a methodology that seeks comprehension of the belonging sings in the communities of Agrovila and São João, both based in the Sustainable Development 
Reserve of Tupé located in Manaus, State of Amazonas, Brazil.

This research presents a methodological contribution supported by a proposition of sustainability indicators. As a result, it is shown a relation of variables related to indicators that allows the identification of the belonging sings reasons (populations displacement) in communities located at a Sustainable Development Reserve. The study shows subsides to intervention and modifications in the reality seeking for the sustainable development.

\section{RESEARCH METHODOLOGY IN SUSTAINABILITY}

The existent gap in the methodological approaches in studies related to sustainability, usually occurs because the approaches in this field still remain linked to classic scientific conventions instead of integrated and interdisciplinary paths (Fahy \& Rau, 2013).

In this sense, the complexity of the problems related to the sustainable development requires linked systems, interrelated indicators, as well as the aggregations of different indicators of sustainability measurements, which embodies the purpose of this study (Bellen, 2008).

Studies that considers an integrated and interdisciplinary approach of the research methodology in sustainability are essentials to investigate aspects inherent and peculiar of a reality as seen in a Sustainable Development Reserve. The gap of research in this area reinforces the importance of oriented methodologies propositions, essentially, focused in questions related to the sustainability area as intended to be shown in the present study.

\section{I THEORETICAL ASPECTS}

Over the 1970 and I980 decades, many studies were developed focusing on stablishing sustainability indicators. However, during that period, those indicators were restricted to the economic development. Nordhaus and Tobin (1972) work became the first main reference when it comes to think about sustainability indicators. After that, the "Index of Sustainable Economic Welfare" (Isew) was created by Herman Daly and Cobb Junior (1989) which represented an enormous contribution to the sustainability indicators debates (Veiga, 2010).
The use of the adjective "sustainable" to qualify the development only started to be used in international debates in 1979, becoming popular after 1987, when "Our common future" report was released by the Brundtland Commission. The idea of developing specific indicators to sustainability appeared during the Eco92, through the Agenda 2I. The chapter 8 of the document express the necessity of developing sustainability indicators (Silva, Freire \& Silva, 2014).

During the 1990 decade other paths were explored in an effort to propose sustainability indicators. That effort resulted in three approaches: (i) build of big and eclectic collections (dashboards), which can be considered as data bases, however because they are too heterogeneous, in priori can't be understood as indicators (Unece/Oecd/Eurostat, 2008); (ii) composed or synthetic index, with many dimensions, which the variables are some picked data from the already mentioned collections; (iii) index focused on the overconsume, underinvestment or excessive pressure on resources (Veiga, 2010).

Starting at the year of 2000, the literature started to present new propositions about sustainability indicators, highlighting Bellen (2002), and Lawn (2006). Bellen's work (2002) represented a great impact by discussing the importance of sustainability measurements (environmental and development). Lawn's work (2006) presented a very deep and detailed approach on this subject, but also presented the difficulties in stablishing indicators able to reveal, simultaneously, the sustainable degree of the socioeconomic process, and the resulting welfare degree (Veiga, 2009).

The study conducted by Scandar Neto (2006) contemplates an important contribution about indicators to the environmental politics. The author proposition, about sustainable development indicators creation and representation, is to overcome the dichotomic relation between "indicators systems" (dashboards) and "synthetic indicators" (aggregated) (Veiga, 2009).

In terms of indicators the Organization for Economic Co-operation and Development (OECD, 2002, p. 7) proposes a set of environmental indicators, as well as socioeconomical and sectorial indicators important from the environmental point 
of view. In this sense, the report "Towards the sustainable development: environmental indicators" from OECD presents a relation among environmental indicators, environmental performance, and sustainable development. It is a relevant document for the "elaboration of environmental components to the sustainable development".

However, it is possible to observe that the indicators pointed by OECD (2002) are supported by the pragmatism as an epistemological conception. The concern about the performance of the member countries evaluation is reinforced as the document offers elements to comparison between the reached results and the reached progress in terms of sustainable development on national and international level.

In a study conducted by the Brazilian Institute of Geography and Statistics (IBGE in Portuguese) about social indicators Simões, Alkimin and Santos (20I7) highlight that the UN agenda about the Sustainable Development Goals (SDG) is a conceptual guide based on sustainability. It is recognized the importance of IBGE in the sense of social information dissemination that can be used as foundation to the design of public politics that can contribute to set the Brazilian development horizon (Simões, Alkimin \& Santos, 2017).

In this context Jannuzzi (2016), affirms that "indicators are, basic inputs required to all stages of the formulation, implementation, and evaluation process of the public programs and politics".

The diversity of indicators related to sustainability is a reflex that the concept about sustainability is still not consensual and universal (Silva, Freire \& Silva, 20I4). In this sense, there is a growing needing to seek for more suitable indicators systems, considering that organizations and many social actors are in constant battles on what to measure and what are the correct decisions to be taken from the information collected in the adopted method (Guimarães \& Feichas, 2009). All of these arguments seek to improve the environmental information base, to auxiliary in the public politics development, to simplify focal researches, and to assure comparability between different locations. The best solution to measure the sustainability of the development depends on the adopted method, but can't guarantee its perfect measurement (Araújo, Fernandes \& Rauen, 2015).

\subsection{SUSTAINABILITY INDICATORS}

The term "indicator" derives from the Latin "indicare", which means to point, to discovery, or to announce. The indicators can be understanding as a resource to make a phenomenon more perceptive, and also to inform or communicate a progress towards a target (Bellen, 2008).

The present study adopted the Scandar Neto (2006, p. 12) definition of indicators: "Indicator is a sign, which means, something that represents something to someone [...] an indicator is a variable, an operative representation of an attribute (characteristic, quality, property) of a system”.

According to Carvalho and Sposto (2012), indicators are used to measure the performance and monitoring goals, objectives, and trends, to compare places and situations, to allow an early alert, and to anticipate conditions and future trends. The main indicators characteristics are: a) relevance, which means clear connection to the target performance; b) objectiveness, based on reliable information; c) accessibility, trustable data; d) readability, understandable by the community; e) measurability, and f) sensibility, in a way its use can be trustworthy.

In addition, it is important to emphasize that indicators are important to the construction of opinions about systems conditions, in the past, present, and in the future (Araújo, Fernandes \& Rauen, 2015). In the sustainability field, indicators can be considered as the main process evaluation component regarding the so-called sustainable development (Oliveira, Francisco \& Goes, 2013).

Regarding the sustainable development goals, they search for: i) subsidize sustainability reporting and; ii) help in the decision make to promote sustainability.

From the point of view of their easiness, indicators defined in more restricted areas of evaluation should align to the indicators and goals to the sustainable development defined on national and international level (Carvalho \& Sposto, 20I2). Related to measurement and definition, indicators can be quantitative and qualitative (Araújo, Fernandes \& Rauen, 2015). Donnelly et al. (2007) and Silva, Selig and Morales (2012) all point out that indicators must be clear and simple. Sustainability repots are in general based on easily measurable indicators, and also, include 
a combination of measurements and predict future development actions (Petrie et al., 2007).

Sustainable Development Indicators are study under different perspective and dimensions. Each one of them contributes to a conceptual understand of the implementation and phenomenon practices that can allow the Earth to have a livable and promising future (Losano, 2008). In spite of the existence of multiple sustainable development dimensions, this study considers Ignacy Sachs propositions. According to Sachs (2008), to a development (of a nation, company, community, etc.) be considered sustainable it has to contemplate five dimensions: environmental, spatial, cultural, social, and economic.

a) Environmental dimension or natural capital involves the natural resources preservation and the expansion of the Earth's capacity, maintaining its deterioration on a minimum level. It is divided by the author in three subdimensions: i) ecological, habitat and forests diversity; ii) water and air quality (pollution), human health protection through chemical and pollution contamination reduction; iii) conservation and management of renewable and non-renewable resources.

b) The spatial dimension or territorial is linked to the human activity's distribution to a better preservation of the biological diversity. It seeks equilibrium among rural and urban populations distribution in the territory and the reduction of the excessive concentration in the metropolitan areas.

c) The cultural dimension is related to the necessity of acceptance of the improvement without cultural identity in each context. It considers specific cultural values inherent to each society, promoting a process searching for changes inside the cultural permanence and able to translate the normative concept of eco-development in a set of specific solutions to the ecosystem.

d) The social dimension searches for an economic development associate to a world's population quality of life improvement, which means, greater equity in income distribution, health, education, and job opportunities improvements, reducing the gap in the concentration of goods and wealth.

e) The economic dimension includes not only the formal economics, but also the informal activities that predict services to individuals and groups and increase, in that way, the monetary income and the individual standard of living. It involves efficient management and allocation of the resources and of a constant flow of public and private investment. f) The economic deficit must be evaluated in macrosocial terms, and not only by the business rentability criteria of micro economical character.

These dimensions agree with the idea that by thinking about sustainability, it must be consider the complexity around humans, their histories, values, concepts and many other factors that compose their totality as human beings. Their humanity is built on a set of variables: the relation between men and their living environment; the factors that influence directly this relation from family heritage to cultural heritage; geographical characteristics; environmental predominant culture; the worldview and the expectation for the future. Therefore, the sustainability, in the broad sense of the expression, can only be understand and captured on its multiple dimensions (Viegas, 20I4).

According to Bellen (2008, p. 13I) "the dimensions use, or a group of grouped indicators, could facilitate the use of measurements that go beyond the pure economic factors and include a signal balance derived from the human and ecological well-being".

The gap of researches in this area reinforces the importance of guided methodologies propositions, essentially, for questions about sustainability on a longitudinal perspective as this study intends to highlight.

\section{CONTEXT ANALYSIS IN SDR FOR THE PROPOSI-} TION OF SUSTAINABILITY INDICATORS

This topic has the intention to present a proposition of sustainability indicators in the context of a Sustainable Development Reserve. However, it is also important to present the context that was taken in consideration to base their elaboration.

\section{I SDR CONTEXT ANALYSIS}

When analyzing a Sustainable Development Reserve it is necessary to consider that in capitalistic societies, in general, the economic conditions, as land access, productivity drop, competition, transportation difficulties, and also lack of opportunities, precariousness and work and income absence, are pointed in demographic studies as main factors to population dislocation (Brito \& Souza, 2005). At first, people want to stay where they live. If they do differently it is because they 
realize that they can't guarantee the subsistence of themselves and their families if the life condition remains the same in that local (Fausto, I999). In this study and for the communities analyzed this perception received the name of "belonging signs".

Following the extended concept of territory (Haesbaert, 2007), where antrophological and sociological perspectives added to the geographic fundamentum of the term, it is considered the existance of indicators, signs or prints that identifies the situations here mentioned as belonging. Belonging to a place, a neighborhood, a community, or any form of habitation, added to the desire to stay there, depends on the possibility of desires and needs satisfaction that are realized in the collective, and on the impossibility of finding it fully or adequately carried out in another locality. By the feeling of belonging the identities are, over the time, territorialy defined by the material and material elements, a set of meanings, representations, and symbols that aggregates to the places and spcaces (Almeida, Vargas \& Mendes, 20II).

Desires and needs gather many definitions and possibilities of satisfaction, accordingly to the cultural universe where the individuals are. When it refers to the plan of social life, however, it is considered the job and income situations; the proximity of economic resources, social, cultural, as goods exchange, services, and neighborhood values; dislocation and mobility conditions; health, education, and security attendance; ultimately, to the set of goods, services, and mechanisms interactional that allows the perception of well-being of the individuals (Siqueira \& Padovam, 2008). The same way, the quality of access to these items it is also indicative of the quality of life that people hope to find in their place of living. Given that, this is a subjective dimension, the difficulty it is not finding the components that build quality of life for any individual in particular, but how the reflection of different factors is important in the individual decision of leaving or staying.

\subsection{BELONGING SIGNS: PERMANENCE AND CONTI- NUITY IN THE TERRITORY}

To understand the concept of "belonging" it is fundamental to understand the associations that human beings make for their psychosocial building and physical survival. Belonging to a group and feels part of something bigger than themselves satisfies primary needs that they try to realize into the collective. Live, stay or change the place of residence, in this perspective, are decisions taken following the limits and the possibilities of the social place they are in. The social place does not reduce itself to the space change, of the relations or the human togetherness, because, it is at the same time, the environmental space, the politic, social, cultural, and economic space, and urbanity. It is when the geographical space becomes territory (Araújo \& Soares, 2009).

In summary, territory is a space socially build. It comprehends both the environmental dimensions compound by the elements of the physical environment, such as types of soil, vegetation variety, hydric resources, and specific fauna, as well as social and spatial dimensions in multiple forms of human interaction and intervention: buildings, constructions, produced or incorporated techniques in the local knowledge, the productive relations, the communications, and the links of all orders that aggregates to the individuals (Mariosa et al., 20I4). Even though its spatial nature, the territory it is above all a relation perceived in a particular way by social groups, mediated by economic, politic, cultural, elements, despite being founded in concrete geographical components (Haesbaert, 2007; Kovalski, 2016).

The territorial singularities occur because of the contribution and the endure of at list two set of strengths (Almeida, 2orr; Almeida, Vargas \& Mendes, 20II). At one side, as foundations and structural elements, there are the environmental variants, as climate, soil, relief, rain season, temperature and atmospheric pression, typical flora and fauna of a certain region, that configurates the natural environment or physical environment where human practices take place. On the other side, the techniques, forms of relation and social interactions, building standards and demographics, productive strengths stage, habits, beliefs, norms and rules of convivence that configurates the sociocultural environment, because describes the social practices developed in the space. These historic social and environmental strengths, therefore, individualize the communities, by giving the, the basic elements to their identity (Leff, 2009). 
In both individual and collective levels, the bond with the local take place at the habitation. Habitations are a type of survival models or cells. They allow the human adaptation to the aggressive conditions of the external environment such as, cold, heat, wind, rain, and other climate and geological events. They are also units of social integration. The drawing, the techniques and the materials used on its edification; the adorns and equipment's incorporated; the dimensions and the local they are placed, for example, are much more than architectonic and built resources, expression of taste or the individual art. More than just simple aesthetics demonstration, they carry a language, which the symbolism separates, classifies, organizes, and hierarchy their occupants between the many social extracts (Schlapfer et al., 20I4).

Habitation aggregates are also social aggregates. Urbans sitios has limits and conditions of habitability, given by the natural characteristics of their localization and the infrastructure and services availability. Well structured, rivers, lakes, green areas aggregate commercial value to the land; when they do not, they devalue the places of dwelling, when present some degradation, like bad smell, accumulation of garbage or deficiency of infrastructure. The urban space is different internally as it distributes unfairly the benefits of the productive processes. Among the urban way of life and the environmental quality, the spaces appropriation occurs accordingly to the socioeconomic status of each social group. While some enjoy the benefits of an entire needed infrastructure necessary, other social groups face lack of habitation, basic sanitation, security, public transportation, waste collection, schools and hospitals (Gomes, 2oro).

What is the extension of the urban? In many populational nucleus from the actual Amazon, multi-located families and urban yards reveal a type of relation that can be classified as "extensive" between rural and urban (Amaral et al., 2013). Riverine and indigenous communities, rural settlement projects in conservation units and socio-spatial formation similar, once characterized as rural, insert themselves in the urban space with social demands for transportation, work and income, education, health services, and job access becoming a "integrated part of the expansion of the rural areas and vice versa" (Amaral et al.,
20I3, p. 372). In this respect, the spatial contiguity, besides not solving the deficiencies and difficulties often found in some social agglomerate clusters, accentuates them.

The condition of material shortage, isolation or exclusion that some individuals and social groups are exposed in their habitation place constitutes in a source of social, collective and individual suffering, that make them face the feeling of loss of bonds or any other discomfort inciting the desire of change. Among the first signals and actual departure there is, however, a period of hesitation or resilience that tends to be more or less extended in reason of the past history or de bonds of each one of them or the possibility of finding places with better opportunities and viable to the individual conditions and expectations, as the rural reminiscences in urban areas or the utopic expectations in the contradicted spaces of the urbanity (Souza, 2010). This bond with the local or "belonging" it is above all a process.

As a process, more than indicate a pure endogenous dimension of insertion of the individuals in particular the social and environmental configuration, it is recognized that the belonging conditions as an interface, a permeable frontier between "individual" and "society" (May, 20II). From the sociological point of view, this understandment of the concept of belonging is based on the well-stablished, of overcoming the individual-social antinomy (Elias, 1994; Giddens, 2009), and it is to the development of explicative schemes that allow the observation of fluid observations produced by the individuals and where they are produced. From the anthropological point of view, it is the establishment of the conception of belonging as the tension among identity and otherness underlying the concept of culture, where new knowledges are incorporated to the traditional ones, where the endogenous completes the exogenous, and the local speaks with the global (Bauman, 20I2; Challinor, 20II).

In this sense, the materialized signs of belonging here analyzed are taken not only as "significant" that express "significance" of the bond level of the individual to the local, but the beginning point where the set of human abilities, interacting with the life of the things produce constructive artifacts to their environment (Ingold, 2000, 20I2). The "belonging signs" configurates as 
a purpose that express the articulation not hierarchical between abilities, visions, techniques, ethics and aesthetics that produces the permanent tension among "me" and the "other" in many different dimensions where this clash may emerge. Capture them, because of that, is a challenge.

This study considers that the social agents responsible for the decision-making process are called residents. In the observation of the habitations destined to be residences, some details in the dwelling space identifies the conservation care, the ornamentation, and correct maintenance of their inhabitants demands. These are analytically important because they require the practice of activities that need resource investments, as time, physical and financial effort to make them look functional and pleasant to the place where they live. Such details indicate commitment, that's why here they are called "belonging signs". When there is a noticeable concern about the quality of life of the residents of a house in a particular area, this feeling becomes perceptible in the way people treat their things, objects, and their spaces. This care reveals the involvement with the place's destiny, the future of their practices, and the satisfaction with the way their projects are taken.

Belonging signs indicate the presence of a reality of sociopsychological nature in the artefacts and objects of use and handling. It is an indicator that has no pretention to describe or explain the reality, but to synthetize it in an objective pattern, in general, of numerical nature, which alterations and tendencies can be follow over the time and space (Jannuzzi, 20r6). Produced in successive moments, the indicator allows the dynamic monitoring of the investigated situation, exposing behaviors imperceptible through analysis of isolated data (Bellen, 2008; Sobral \& Freitas, 2010).

In a more ample perspective, searching for a construction and the study of indicators of socioenvironmental quality, the use of variable here designated as "belonging signs" implies that socio-cultural practices, techniques, and costumes found and measured in the constructions are associated with prospects of long-term permanence or not of its residents.
3.3 PROPOSITIONS OF SUSTAINABILITY INDICATORS IN THE CONTEXT OF SDR

The intention to consider the sustainable development dimensions of Sachs (2008) to the formulation of sustainability indicators stimulates the presentation of the indicators from what Bellen (2006, p. 43) considers as "stablished or desired values by the governmental authorities or achieved by a social consensus".

Aiming to encompass the sustainable development dimensions from indicators, this research is based on a set of indicators categorized as environmental, spatial, cultural, social, and economic. Therefore, the synthetic indicators approach is used to cover the dimensions, and their respective indicators and variables based on Scandar Neto's (2006) work.

The proposal is to identify the variables related to indicators that can be used to develop studies with different purposes such as, in this case, the communities of São João do Tupé and Agrovila both located at the Sustainable Development Reserve of Tupé, in Manaus/ Brazil (Chart I). RDS Tupé is composed of six riverside communities (Figure or), but only two were studied.

Some of the indicators and variables pointed in Table I will be applied in this study seeking to validate the methodology proposed bellow.

4. PROPOSAL OF SUSTAINABILITY RESEARCH METHODOLOGY IN THE CONTEXT OF SDR

The goal of this section is to present a research methodologic proposal in sustainability that can make possible to answer the questions presented in this study, in another words, to identify what are the sustainability indicators applicable to study the belonging of people living in a Sustainable Development Reserve.

This methodological proposal shares a concern with Social Sciences, which have been highlighting the importance of methodological approaches that can capture social and environmental phenomenon neglected by many studies. However, it is recognized that the task of align sustainability with significant empirical observations is as challenge. This occurs because the approach of methodological research in sustainability is still connected to traditional scientific conventions and not with 
Chart 1 - Indicators related to the environmental, spatial, cultural, social, and economic dimensions, in the context of Sustainable Development Reserves

DIMENSIONS
INDICATORS

VARIABLES

VARIABLES

\begin{tabular}{|c|c|c|c|c|}
\hline \multirow{3}{*}{ Environmental } & Soil use & Family farming & $\begin{array}{l}\text { Extractive } \\
\text { activities }\end{array}$ & Medicinal plants \\
\hline & habitat diversity & Presence of animals & $\begin{array}{l}\text { Presence of plants } \\
\text { (yard, vegetable } \\
\text { garden) }\end{array}$ & \\
\hline & $\begin{array}{l}\text { Ecosystem } \\
\text { preservation }\end{array}$ & $\begin{array}{l}\text { Management plan in } \\
\text { protected areas }\end{array}$ & Sanitation & Waste control \\
\hline \multirow{3}{*}{ Spatial } & Habitability & $\begin{array}{l}\text { Housing situation } \\
\text { (under construction, } \\
\text { occupied, vacation, empty, } \\
\text { abandoned) }\end{array}$ & $\begin{array}{l}\text { Confort (acoustic, } \\
\text { illumination, } \\
\text { ventilation) }\end{array}$ & $\begin{array}{l}\text { Types of coating } \\
\text { (wall and floor); } \\
\text { Painting; Miter }\end{array}$ \\
\hline & $\begin{array}{l}\text { Demographic } \\
\text { concentration }\end{array}$ & $\begin{array}{l}\text { Population living in rural } \\
\text { areas }\end{array}$ & $\begin{array}{l}\text { Population living } \\
\text { in urban areas }\end{array}$ & \\
\hline & $\begin{array}{l}\text { Housing spatial } \\
\text { distribution }\end{array}$ & $\begin{array}{l}\text { Houses of fixed } \\
\text { inhabitants (central core of } \\
\text { the community); Houses } \\
\text { of eventual inhabitants } \\
\text { (vacation); Inhabitants } \\
\text { residences in crop areas }\end{array}$ & & \\
\hline \multirow{5}{*}{ Cultural } & Ethnic groups. & $\begin{array}{l}\text { Indigenous people; } \\
\text { Riverine; Quilombolas; } \\
\text { Forest people; } \\
\text { Colonization nucleus }\end{array}$ & & \\
\hline & Family heritage & $\begin{array}{l}\text { Tradition (natural medice; } \\
\text { parties; fairs; tale; local } \\
\text { stories) }\end{array}$ & & \\
\hline & $\begin{array}{l}\text { Local bond } \\
\text { (belonging) }\end{array}$ & $\begin{array}{l}\text { Cultural identity and } \\
\text { belonging feelings }\end{array}$ & Local knowledge & \\
\hline & Schooling & $\begin{array}{l}\text { Access to formal education } \\
\text { system }\end{array}$ & Informal education & Educational stage \\
\hline & Accessibility & $\begin{array}{l}\text { Information and } \\
\text { comunication technologies }\end{array}$ & Information access & \\
\hline
\end{tabular}


Chart 1 - Indicators related to the environmental, spatial, cultural, social, and economic dimensions, in the context of Sustainable Development Reserves (cont.)

DIMENSIONS

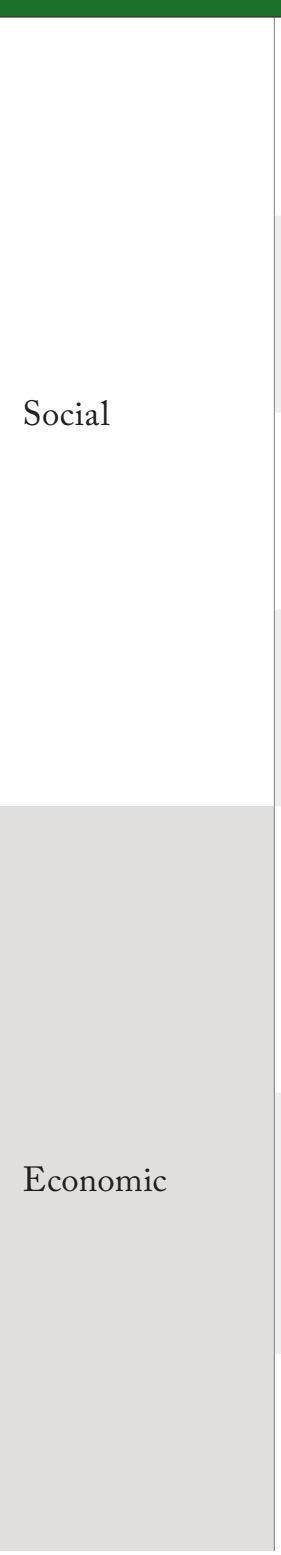

INDICATORS

VARIABLES

\begin{tabular}{|c|c|c|c|}
\hline $\begin{array}{l}\text { Work, income } \\
\text { and job } \\
\text { conditions }\end{array}$ & Formal and informal & $\begin{array}{l}\text { Fixed income and } \\
\text { variable income }\end{array}$ & $\begin{array}{l}\text { Seasonality of work } \\
\text { and income due to } \\
\text { harvests and animal } \\
\text { husbandry }\end{array}$ \\
\hline $\begin{array}{l}\text { Social } \\
\text { interaction }\end{array}$ & Work relationships & $\begin{array}{l}\text { Neighborhood } \\
\text { relationships }\end{array}$ & $\begin{array}{l}\text { Relationships in } \\
\text { typical community } \\
\text { events (politics, } \\
\text { sports, and religious) }\end{array}$ \\
\hline $\begin{array}{l}\text { Relationships } \\
\text { and norms of } \\
\text { coexistence }\end{array}$ & $\begin{array}{l}\text { Respect to the social } \\
\text { contract (Community } \\
\text { environmental and social } \\
\text { norms) }\end{array}$ & & \\
\hline $\begin{array}{l}\text { Human health } \\
\text { protection }\end{array}$ & Access to health services & $\begin{array}{l}\text { Knowledge and } \\
\text { proper plant } \\
\text { husbandry }\end{array}$ & $\begin{array}{l}\text { Knowledge and } \\
\text { proper animal } \\
\text { husbandry }\end{array}$ \\
\hline $\begin{array}{l}\text { Job (main } \\
\text { occupation) }\end{array}$ & $\begin{array}{l}\text { Public agent; Retired; } \\
\text { Permanent job; } \\
\text { Agriculture; Commerce; } \\
\text { Tourism; Eventual job; } \\
\text { Student; Minor; and No } \\
\text { academic degree }\end{array}$ & & \\
\hline Main income & $\begin{array}{l}\text { Minimum Wage (no } \\
\text { income; up to or MW; } \\
\text { from or to O2 MW; from } \\
\text { O2 to O3 MW; more than } \\
\text { o4 MW) }\end{array}$ & & \\
\hline Production & Machines and equipments & $\begin{array}{l}\text { Production } \\
\text { financing }\end{array}$ & $\begin{array}{l}\text { Destination of the } \\
\text { production }\end{array}$ \\
\hline
\end{tabular}

Source: Elaborated by the authors.

integrated and interdisciplinary approaches. Nonetheless, the research methods should not be seen only as methodological options to researchers, but as ways of reflecting different ontological and epistemological visions that take into account their visions of social world (Fahy \& Rau, 2013).

In this sense, based on the methodological assumptions of Fahy and Rau (2013), and also considering the many interests and peculiarities (social, economic, environmental, cultural, and spatial) regarding to a Sustainable Development
Reserve the methodological scope of this research is presented.

The presented research methodologic is characterized as qualitative, longitudinal, and ecological study. The qualitative approach intends to understand the logic of process and social structures by deep analysis of one or a few particular cases (Cebrap, 2016). According to Gil (2019) qualitative research seeks to explain the systematic of facts that occurs on the social context that, in general, is related to a multiplicity of variables. To 
Chizzotti $(2005$, p. 89$)$ the main purpose of qualitative researches "is to intercede on an unsatisfying situation, change conditions noticed as changeable", which goes accordingly to this study goals.

To Fahy and Rau (2013) longitudinal studies is a type of research in which the information and data are collected and registered during a long period of time maintaining the same sample. This way, it is possible to make the analysis of social and ecological changes present in the reality studied. It is important to point out that studies about sustainable initiatives from a longitudinal methodological approach are incipient as showed by Fahy and Rau (2013). Regarding the longitudinal amplitude, the present study corresponds to interventions made over the years of 2009, 2010 , 20I3, 20I4, and 2018.

Additionally, this research methodology characterizes as an ecological study, because it is based on analysis of populational groups in specifics geographical areas and not in particular individuals. Thus, individual-level data are absent in the conjunct distribution of variables within groups. Variables in an ecological analysis can be aggregated measures, environmental measures or global measures. The ecological study allows, among other alternatives, measure if the individuals are grouped by local (multiple group study), by time (temporal series), or by time and local (mixed study) (Medronho, 2009; Morgenstern, 1995).

The sample of the study is "by convenience" type, in other words, the population groups were chosen by their characteristics and by the facility of the data access by the researchers, following Richardson (2017) instructions. The sample space comprises the entire population of São João of Tupé and Agrovila, two of the six Communities from the Sustainable Development Reserve of Tupé (SDR of Tupé), in Manaus, Amazonas. Based on the information regarding the years mentioned above this study discusses the socio-anthropological sense of belonging associated to "belonging signs" indicators and variables, "occupational profile", and "income" of the communities. From the proposition of a theoretical-practical framework of indicators and variables, only those that met the goals of this study were chosen and applied. The investigates populational groups did not receive any special statistic treatment.
The general aspects and conditions of the Communities were raised by straight observation and semi-structured interviews with the residents. The data representative of the belonging signals was collected from a field survey, carried out in the years of 2009 and 2013 , by semi-structured forms created based on the theoretical discussion presented in the "Belonging Signs: permanence and continuity in the territory" topic.

Residents information were gathered between the years of 2010 and 2014, by the application of semi-structured questionnaires, emphasizing the sociodemographic variables of main occupation and monthly income. In 20I8, the populational dislocation trend was object of local verification through observational study.

For the participants selection of this research it was selected residences located in the central areas of the communities of São João of Tupé and Agrovila. After that, Excel spreadsheet resources were used to raffle addresses of residents to be interviewed. For this selection it was considered a minimum interval of $95 \%$ of statistical trust, sampling error of $5 \%$, and the proportionality of the spatial concentration of the residences. The original data obtained were systematized through descriptive statistics procedures in measures of average centrality and relative frequency, and interpreted by comparing historical series.

\section{PRESENTATION AND RESULTS ANALYSIS}

5.I PRESENTATION OF THE COMPONENTS OF BELONGING SIGNS IN SDR TUPÉ: TYPIFICATION

The SDR of Tupé (Picture I) it is a Conservation Unit located in the state of Amazonas, close to the urban center of Manaus, where it is around ${ }_{25} \mathrm{Km}$ distant from the central point of the city, in straight line. It was created through the Municipal Decree no 8044, of August 25, 2005, it has an area of Ir.973 hectares, occupying an almost regular quadrilateral between the Tatu and TarumãMirim igarapes. At the south, its limits are the Rio Negro (Negro River); at east, the TarumãMirim Igarape; at west-north, the Sustainable Development Reserve of Puranga Conquista.

Located in the internal perimeter of Tupé SDR there are six communities: Tataulândia, São 
Figure 1 - Location map of Riveri Communities of Sustainable Development Reserve of Tupé, Manaus, Amazonas

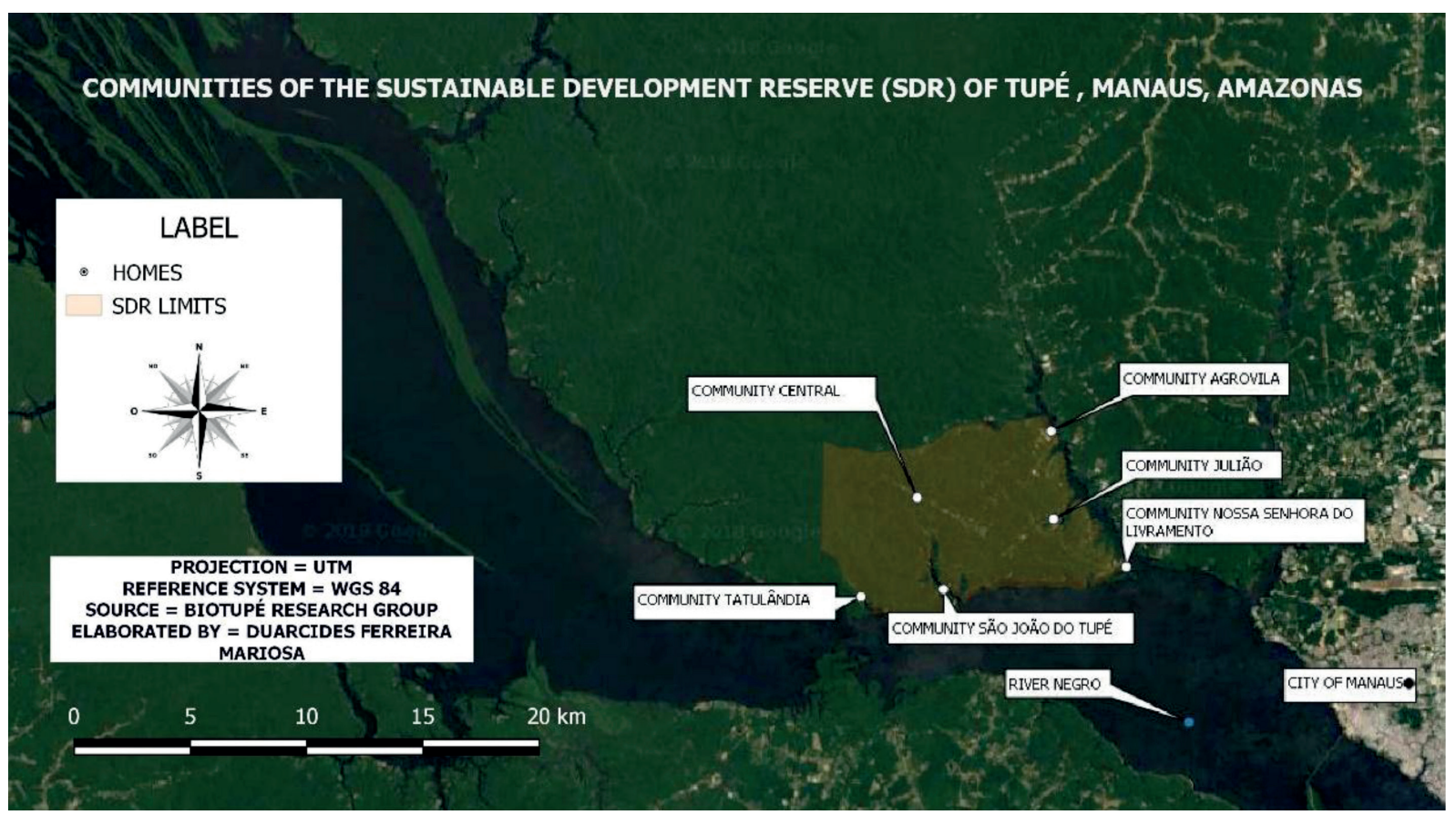

Source: Elaborated by the authors.

João do Tupé, Central, Julião, Livramento, and Agrovila (Marchand, 20r4; Santos-Silva, Scudeller \& Cavalcanti, 20II).

For the belonging signs study the unit of analisys chosen was the residences. There, acording to Mariosa et. al. (20I4), the visual and measurable characterics of the houses and constructions that show commitment were individualy collected from those located in the central áreas of the community. For the income and occupational profile exam, the unit of análisis choosen were the residents that actual live in the community, and from them, were collected in a sample form, data about the ocupational profile and the values received as income, salary or benefit.

Because of the specificity of the considered local - riverine communities located in sustainable development reserve - there were used some variables associated to indicators proposed in the chart I, to dimension the bond between residents and local habitation: the habitation situation or the way it is used; vegetable garden presence, animals and gardens located near be buildings or yards; types of wall painting, miter, and coating applied in cold areas used in the construction base. Each one of the variables received a "score" or weight that goes from o (zero) to io (ten), accordingly to the less or more reveal of the resident's intention to stay at the local and as the theorical orientation described to the set of variables.
Yards refers to the land extension located at the adjacencies of the houses, where trees, bushes, herbs, and fruit plants are cultivated to be used as food, source of income or medicinal use (Chart 2). Culturally, the yards are filled with tradition, knowledge passed through generations, leaving in the space over the time the signs of human adaptability and the particular identity of a people, society or social group (Geertz, 200I).About the visible belonging signs of the constructions, the first situation to be observed it is about the use or destiny reserved to habitations (Chart 3). The existence of habitations in construction is a variable that demonstrates that the local is somehow attractive for those who wants to stay there. The habitations occupied as residences indicate that de bonds with the local are or were consolidate to those residents. The touristic constructions, reveal the paisagistic or natural environment value to the people that build there, but the bond stablished, however, is from another nature in reason of, most of the time, their occupants live in another locality. The empty habitations indicate the intermittent relation with the local, the same way as the quantity of abandoned habitations reflects the low activities.

In the base of the constructions there are variables filled with strong environmental, spatial, cultural, social, and economic meaning. 
Chart 2 - Variables and weight of the components of belonging signs found at the yards

\begin{tabular}{|c|c|c|}
\hline VARIABLE & DESCRIPTION & $\begin{array}{c}\text { CONTAINED INFORMATION } \\
\text { RELATIVE WEIGHT OF THE ANSWERS TO THE VARIABLES: } \\
\text { GREAT (10); GOOD (8); MEDIUM (6); REGULAR (4); } \\
\text { TERRIBLE (2); OR INEXISTENT (0) }\end{array}$ \\
\hline \multirow{3}{*}{$\begin{array}{l}\text { Vegetable } \\
\text { Garden }\end{array}$} & \multirow{3}{*}{$\begin{array}{r}\text { Presence of flower beds, vases or cultivated } \\
\text { spaces }\end{array}$} & - of diversified species (Iо) \\
\hline & & - with only one specie or monoculture (6) \\
\hline & & $\bullet$ inexistent $(\mathrm{o})$ \\
\hline \multirow{5}{*}{ Garden } & \multirow{5}{*}{$\begin{array}{l}\text { Presence of flowers, trees, and ornamental } \\
\text { plants cultivated and the disposition in the } \\
\text { area }\end{array}$} & - in prepared beds (го) \\
\hline & & - vases with plants (8) \\
\hline & & $\cdot$ fruit trees $(6)$ \\
\hline & & - lawn (4) \\
\hline & & - inexistent (o) \\
\hline \multirow{2}{*}{ Animals } & \multirow{2}{*}{$\begin{array}{r}\text { Presence of domestic animals and/or } \\
\text { fellowship }\end{array}$} & - presence (Iо) \\
\hline & & - absence (o) \\
\hline
\end{tabular}

Source: Elaborated by the authors.

Chart 3 - Variables and weight of the components of belonging signs found at the edifications

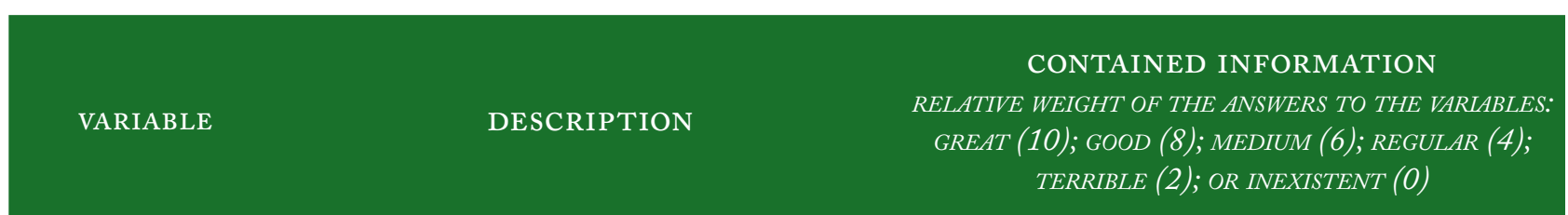

\begin{tabular}{|c|c|c|}
\hline \multirow{5}{*}{$\begin{array}{r}\text { Habitation } \\
\text { situation }\end{array}$} & \multirow{5}{*}{ Destiny or given use of the construction } & - in construction (го) \\
\hline & & $\bullet$ occupied (8) \\
\hline & & - tourism (6) \\
\hline & & - empty (2) \\
\hline & & - abandoned (o) \\
\hline \multirow{6}{*}{ Miter } & \multirow{6}{*}{$\begin{array}{l}\text { Material used in the doors and windows } \\
\text { confection }\end{array}$} & - glass (Iо) \\
\hline & & - aluminium (8) \\
\hline & & $\bullet \operatorname{iron}(6)$ \\
\hline & & $\cdot \operatorname{wood}(4)$ \\
\hline & & - plastic-pvc (2 \\
\hline & & - inexistent (o) \\
\hline \multirow{5}{*}{ Painting } & \multirow{5}{*}{$\begin{array}{l}\text { General aspect of the painting and wall } \\
\text { conservation are evaluated as: }\end{array}$} & - excelent (Io) \\
\hline & & $\cdot \operatorname{good}(8)$ \\
\hline & & - medium (6) \\
\hline & & - regular $(4)$ \\
\hline & & - inexistent (o) \\
\hline \multirow{5}{*}{ Wall coating } & \multirow{5}{*}{$\begin{array}{r}\text { General state of the coatings used in the } \\
\text { cold areas }\end{array}$} & - excelent (Io) \\
\hline & & $\cdot \operatorname{good}(8)$ \\
\hline & & - medium (6) \\
\hline & & - regular $(4)$ \\
\hline & & - there is no such resource in the habitation (o) \\
\hline \multirow{5}{*}{ Floor coating } & \multirow{5}{*}{ Type of insulation applied to the floor } & - ceramic (Io) \\
\hline & & $\cdot \operatorname{wood}(9)$ \\
\hline & & - cemented (8); \\
\hline & & - uncovered floor (2) \\
\hline & & $\bullet \operatorname{other}(2)$ \\
\hline
\end{tabular}

Source: Elaborated by the authors. 
Regarding the internal and external quality of the habitation, the buildings used as residence are specially designed to guarantee the closeness and protection, related to the outside, from those who use it for this purpose. About the comfort, special miters, forefront and coverages guarantee, from the physical perspective, natural illumination, air and heat change, protection against inclement weather, high temperatures and solar radiation harmful to health.

Regarding the sociocultural variables it is important to pay attention to the two-way vision: from the outside to the inside, that supports the privacy of activities of the occupants; from the inside out, that allows the landscape view. In general, opaque elements reduces vision, while translucidus and transparent elements increases it.

It is relevant to consider that the choice of materials and constructional techniques for door frames and windows take into account the noise reduction performance, light control, water and air seal, heat transfer control, and the visibility quality (Duarte, 20II). The choice of what should be used it is determined by the technical-constructive performance, availability, and cost; and for the level of quality necessary to meet the "user satisfaction” (Reis, 20II, p. 2I). Glass, aluminum, and iron, in this order, represent more comfort and duration to the miters - in the climatic context of Amazon - than wood and plastic. The house paintings, as the miters used in floors and wall, also have this double techinic-constructive and aesthetic-decorative character presented in the miters.

\subsection{BELONGING SIGNS AT AGROVILA COMMUNITY}

The Agrovila "Amazonino Mendes", officially funded in April Io, 1994, is located in the extreme northeast of the Tupé SDR, where it is located. It has a main habitational nucleus, where most of the houses are concentrated, a small commerce area, a school, churches, and public areas. Set aside for about three kilometers of this nucleus are the plots, or lots intended for planting and other agricultural practices. A little bit further there are the populations, spread in the margins of the Acácio and Caniço Igarapes.

The Tables I and 2 describes, ordinates, and systematize the indicative data of "belonging signs" to the constructions located at the central nucleus of Agrovila Community in two different moments: 2009 and 2013 .
Considering that the coefficient was built from the weighted average of the variables the compound it, between a maximum limit of "I,O" and inferior of "o,०", the number founded in 2009 $(0,429)$ points to a situation below the median for the belonging degree of the population studied. The low occurrence of houses with animals, gardens and vegetable garden and the non-investment in painting and cold areas coating of the constructions contributed negatively to this result. Positively, it should be noticed that most of the houses use wooden floors and windows which, for the humid and rainy tropical environment, is the most suitable material.

In 20I3, after 04 years since the first data collection, the values that represent the belonging signs suffered some small variations. In Table 2 it is possible to notice that the "belonging signs" were reduced in approximately $6 \%$ during the evaluation period reaching, in 2013, the mark of 0,405 . It raises the attention the fact that the aspects that had a negative impact are still the same: wall coating, vegetable garden, animals, paintings, and gardens. The ones above 0,405 also remained the same: miters, habitation situation, and floor coating. However, taking a close look at the variables, it is possible to notice some slight alterations in ones and profound in others, as pointed out in Figure 2.

Starting by the number of habitations or constructions, that increased from I30 (in 2009) to 175 (in 2013), other variables also had important changes. It was observed that there was reduction in the number of houses with vegetable gardens, animals, gardens, wall coating, and situation of the habitation. On the other hand, there was and increasing in the number of houses painted, with wooden miters and floor coating. It should be considered meaningful to the intention of staying analysis the fact that the habitations in construction and occupied has increased $24 \%$ in the period, going from 97 to 120 units. To indicate possible influences to de flow variability of the habitations, it is proposed to analyze the same variables in the Sao Joao of Tupé community.

5.3 BELONGING SIGNS IN THE SAO JOAO DO TUPÉ COMMUNITY

The Sao Joao of Tupé Community has very distinguish characteristics, in geographical terms, from Agrovila community. The main nucleus of the 
Table 1 - Belonging signs aspects in the Agrovila Communitie at SDR of Tupé in 2009

\begin{tabular}{|c|c|c|c|c|c|c|c|c|}
\hline Habitation & $\begin{array}{c}\text { In } \\
\text { Construction }\end{array}$ & Occupied & Touristic & Empty & Abandoned & $\begin{array}{l}\text { Reached } \\
\text { Points }\end{array}$ & $\begin{array}{l}\text { Possible } \\
\text { Points }\end{array}$ & Coefficient \\
\hline & I7 & 80 & $\mathrm{I} 2$ & I6 & 5 & \multirow{3}{*}{$9 \mathrm{I} 4$} & \multirow{3}{*}{ I3OO } & \multirow{3}{*}{0,703} \\
\hline Given Weight & IO & 8 & 6 & 2 & o & & & \\
\hline Sub-Total & I70 & 640 & 72 & 32 & o & & & \\
\hline \multirow{2}{*}{$\begin{array}{l}\text { Vegetable } \\
\text { Garden }\end{array}$} & Diversified & Monoculture & Inexistent & & & $\begin{array}{c}\text { Reached } \\
\text { Points }\end{array}$ & $\begin{array}{c}\text { Possible } \\
\text { Points }\end{array}$ & Coefficient \\
\hline & 29 & 3 & 83 & & & \multirow{3}{*}{308} & \multirow{3}{*}{ II5O } & \multirow{3}{*}{0,268} \\
\hline Given Weight & IO & 6 & o & & & & & \\
\hline Sub-Total & 290 & I8 & o & & & & & \\
\hline \multirow[t]{2}{*}{ Floor Coating } & $\begin{array}{c}\text { Uncovered } \\
\text { Floor }\end{array}$ & Cemented & Ceramic & Wood & Other & $\begin{array}{c}\text { Reached } \\
\text { Points }\end{array}$ & $\begin{array}{c}\text { Possible } \\
\text { Points }\end{array}$ & Coefficient \\
\hline & 7 & 34 & II & 68 & $\mathrm{O}$ & \multirow{3}{*}{ IO22 } & \multirow{3}{*}{$\mathrm{I} 200$} & \multirow{3}{*}{0,852} \\
\hline Given Weight & 4 & 8 & IO & 9 & 2 & & & \\
\hline Sub-Total & 28 & 272 & IIO & $6 \mathrm{I} 2$ & $\mathrm{O}$ & & & \\
\hline \multirow[t]{2}{*}{$\begin{array}{c}\text { Wall } \\
\text { Covering }\end{array}$} & Excelent & Good & Medium & Regular & Inexistent & $\begin{array}{c}\text { Reached } \\
\text { Points }\end{array}$ & $\begin{array}{l}\text { Possible } \\
\text { Points }\end{array}$ & Coefficient \\
\hline & 0 & 6 & I & II & 99 & \multirow{3}{*}{98} & \multirow{3}{*}{ II7O } & \multirow{3}{*}{0,084} \\
\hline Given Weight & IO & 8 & 6 & 4 & $\mathrm{O}$ & & & \\
\hline Sub-Total & 0 & 48 & 6 & 44 & $\mathrm{O}$ & & & \\
\hline \multirow[t]{2}{*}{ Animals } & Presence & Absence & & & & $\begin{array}{c}\text { Reached } \\
\text { Points }\end{array}$ & $\begin{array}{c}\text { Possible } \\
\text { Points }\end{array}$ & Coefficient \\
\hline & 34 & 79 & & & & \multirow{3}{*}{340} & \multirow{3}{*}{ II3O } & \multirow{3}{*}{0,301} \\
\hline Given Weight & IO & 0 & & & & & & \\
\hline Sub-Total & 340 & 0 & & & & & & \\
\hline \multirow[t]{2}{*}{ Wall Paint } & Excelent & Good & Medium & Regular & Inexistent & $\begin{array}{c}\text { Reached } \\
\text { Points }\end{array}$ & $\begin{array}{c}\text { Possible } \\
\text { Points }\end{array}$ & Coefficient \\
\hline & 2 & 9 & 4 & 22 & $8 \mathrm{I}$ & \multirow{3}{*}{204} & \multirow{3}{*}{ II8O } & \multirow{3}{*}{0,173} \\
\hline Given Weight & IO & 8 & 6 & 4 & o & & & \\
\hline Sub-Total & 20 & 72 & 24 & 88 & o & & & \\
\hline \multirow[t]{2}{*}{ Miter } & Glass & Wood & Aluminium & Iron & Inexistent & $\begin{array}{c}\text { Reached } \\
\text { Points }\end{array}$ & $\begin{array}{c}\text { Possible } \\
\text { Points }\end{array}$ & Coefficient \\
\hline & $\mathrm{I}$ & 90 & 3 & $\mathrm{O}$ & 26 & \multirow{3}{*}{754} & \multirow{3}{*}{$\mathrm{I} 200$} & \multirow{3}{*}{0,628} \\
\hline Given Weight & IO & 8 & 8 & 6 & o & & & \\
\hline Sub-Total & IO & 720 & 24 & o & 0 & & & \\
\hline \multirow[t]{2}{*}{ Garden } & Plant Beds & Lawn & Vases & Trees & Inexistent & $\begin{array}{c}\text { Reached } \\
\text { Points }\end{array}$ & $\begin{array}{c}\text { Possible } \\
\text { Points }\end{array}$ & Coefficient \\
\hline & 30 & o & 5 & $4 \mathrm{I}$ & $4 \mathrm{I}$ & \multirow{3}{*}{494} & & \\
\hline Given Weight & IO & 8 & 6 & 4 & $\circ$ & & II7O & 0,422 \\
\hline Sub-Total & 300 & $\circ$ & 30 & I64 & $\circ$ & & & \\
\hline
\end{tabular}

IQSA RESIDENCES - BELONGING SIGNS - PONDERATION O TO I TO THE REACHED POINT AND THE POSSIBLE POINTS TO EACH ONE OF O8 CONSIDERED VARIABLES - NOT INFORMED WERE DISCARDED 
STUDY ON THE SUSTAINABLE INDICATORS AND RESEARCH METHODOLOGY IN THE CONTEXT OF THE SUSTAINABLE DEVELOPMENT RESERVE OF TUPÉ, AMAZONAS - BRAZIL MARIOSA; DE BENEDICTO; SUGAHARA

Table 2 - Belonging signs aspects in the Agrovila Communitie at SDR of Tupé in 2013

\begin{tabular}{|c|c|c|c|c|c|c|c|c|}
\hline $\begin{array}{c}\text { Habitation } \\
\text { Situation }\end{array}$ & $\begin{array}{c}\text { In } \\
\text { Construction }\end{array}$ & Occupied & Touristic & Empty & Abandoned & $\begin{array}{c}\text { Reached } \\
\text { Points }\end{array}$ & $\begin{array}{l}\text { Possible } \\
\text { Points }\end{array}$ & Coefficient \\
\hline & I9 & IOI & I5 & $3 \mathrm{I}$ & 6 & \multirow{3}{*}{ II5O } & \multirow{3}{*}{$\mathrm{I} 720$} & \multirow{3}{*}{0,669} \\
\hline Given Weight & IO & 8 & 6 & 2 & $\mathrm{o}$ & & & \\
\hline Sub-Total & 190 & 808 & 90 & 62 & o & & & \\
\hline \multirow{2}{*}{$\begin{array}{l}\text { Vegetable } \\
\text { Garden }\end{array}$} & Diversified & Monoculture & Inexistent & & & $\begin{array}{c}\text { Reached } \\
\text { Points }\end{array}$ & $\begin{array}{c}\text { Possible } \\
\text { Points }\end{array}$ & Coefficient \\
\hline & I7 & 9 & $\mathrm{I} 32$ & & & \multirow{3}{*}{224} & \multirow{3}{*}{ I580 } & \multirow{3}{*}{$0, \mathbf{1} 42$} \\
\hline Given Weight & IO & 6 & o & & & & & \\
\hline Sub-Total & 170 & 54 & o & & & & & \\
\hline \multirow[t]{2}{*}{ Floor Coating } & $\begin{array}{c}\text { Uncovered } \\
\text { Floor } \\
\end{array}$ & Cemented & Ceramic & Wood & Other & $\begin{array}{c}\text { Reached } \\
\text { Points }\end{array}$ & $\begin{array}{c}\text { Possible } \\
\text { Points }\end{array}$ & Coefficient \\
\hline & II & 25 & $2 \mathrm{I}$ & 80 & o & \multirow{3}{*}{ II74 } & \multirow{3}{*}{ I370 } & \multirow{3}{*}{0,857} \\
\hline Given Weight & 4 & 8 & IO & 9 & 2 & & & \\
\hline Sub-Total & 44 & 200 & 210 & 720 & o & & & \\
\hline \multirow{2}{*}{$\begin{array}{c}\text { Wall } \\
\text { Covering }\end{array}$} & Excelent & Good & Medium & Regular & Inexistent & $\begin{array}{c}\text { Reached } \\
\text { Points }\end{array}$ & $\begin{array}{c}\text { Possible } \\
\text { Points }\end{array}$ & Coefficient \\
\hline & 0 & 5 & 5 & 9 & $\mathrm{I} 26$ & \multirow{3}{*}{ Io6 } & \multirow{3}{*}{$\mathrm{I} 45^{\circ}$} & \multirow{3}{*}{ o,o73 } \\
\hline Given Weight & IO & 8 & 6 & 4 & $\mathrm{O}$ & & & \\
\hline Sub-Total & o & 40 & 30 & 36 & o & & & \\
\hline \multirow[t]{2}{*}{ Animals } & Presence & Absence & & & & $\begin{array}{c}\text { Reached } \\
\text { Points }\end{array}$ & $\begin{array}{c}\text { Possible } \\
\text { Points }\end{array}$ & Coefficient \\
\hline & 34 & II6 & & & & \multirow{3}{*}{340} & \multirow{3}{*}{ I5OO } & \multirow{3}{*}{0,227} \\
\hline Given Weight & IO & 0 & & & & & & \\
\hline Sub-Total & 340 & o & & & & & & \\
\hline \multirow[t]{2}{*}{ Wall Paint } & Excelent & Good & Medium & Regular & Inexistent & $\begin{array}{c}\text { Reached } \\
\text { Points }\end{array}$ & $\begin{array}{c}\text { Possible } \\
\text { Points }\end{array}$ & Coefficient \\
\hline & 4 & I6 & IO & $3 \mathrm{I}$ & 96 & \multirow{3}{*}{$35^{\circ}$} & \multirow{3}{*}{ I570 } & \multirow{3}{*}{0,223} \\
\hline Given Weight & IO & 8 & 6 & 4 & o & & & \\
\hline Sub-Total & 40 & $\mathrm{I} 26$ & 60 & $\mathrm{I} 24$ & O & & & \\
\hline \multirow[t]{2}{*}{ Miter } & Glass & Wood & Aluminium & Iron & Inexistent & $\begin{array}{c}\text { Reached } \\
\text { Points }\end{array}$ & $\begin{array}{l}\text { Possible } \\
\text { Points }\end{array}$ & Coefficient \\
\hline & 9 & $\mathrm{I} 32$ & 4 & 4 & $\mathrm{I} 2$ & \multirow{3}{*}{$\mathrm{I} 2 \mathrm{O} 2$} & \multirow{3}{*}{ I6IO } & \multirow{3}{*}{0,747} \\
\hline Given Weight & IO & 8 & 8 & 6 & ० & & & \\
\hline Sub-Total & 90 & I056 & 32 & 24 & $\mathrm{O}$ & & & \\
\hline \multirow[t]{2}{*}{ Garden } & Plant Beds & Lawn & Vases & Trees & Inexistent & $\begin{array}{c}\text { Reached } \\
\text { Points }\end{array}$ & $\begin{array}{c}\text { Possible } \\
\text { Points }\end{array}$ & Coefficient \\
\hline & 35 & 6 & 5 & $\mathrm{I} 4$ & 99 & \multirow{3}{*}{484} & & \\
\hline Given Weight & IO & 8 & 6 & 4 & 0 & & I590 & 0,304 \\
\hline Sub-Total & 350 & 48 & 30 & 56 & ○ & & & \\
\hline
\end{tabular}

IQSA RESIDENCES - BELONGING SIGNS - PONDERATION O TO I TO THE REACHED POINT AND THE POSSIBLE

POINTS TO EACH ONE OF O8 CONSIDERED VARIABLES - NOT INFORMED WERE DISCARDED 


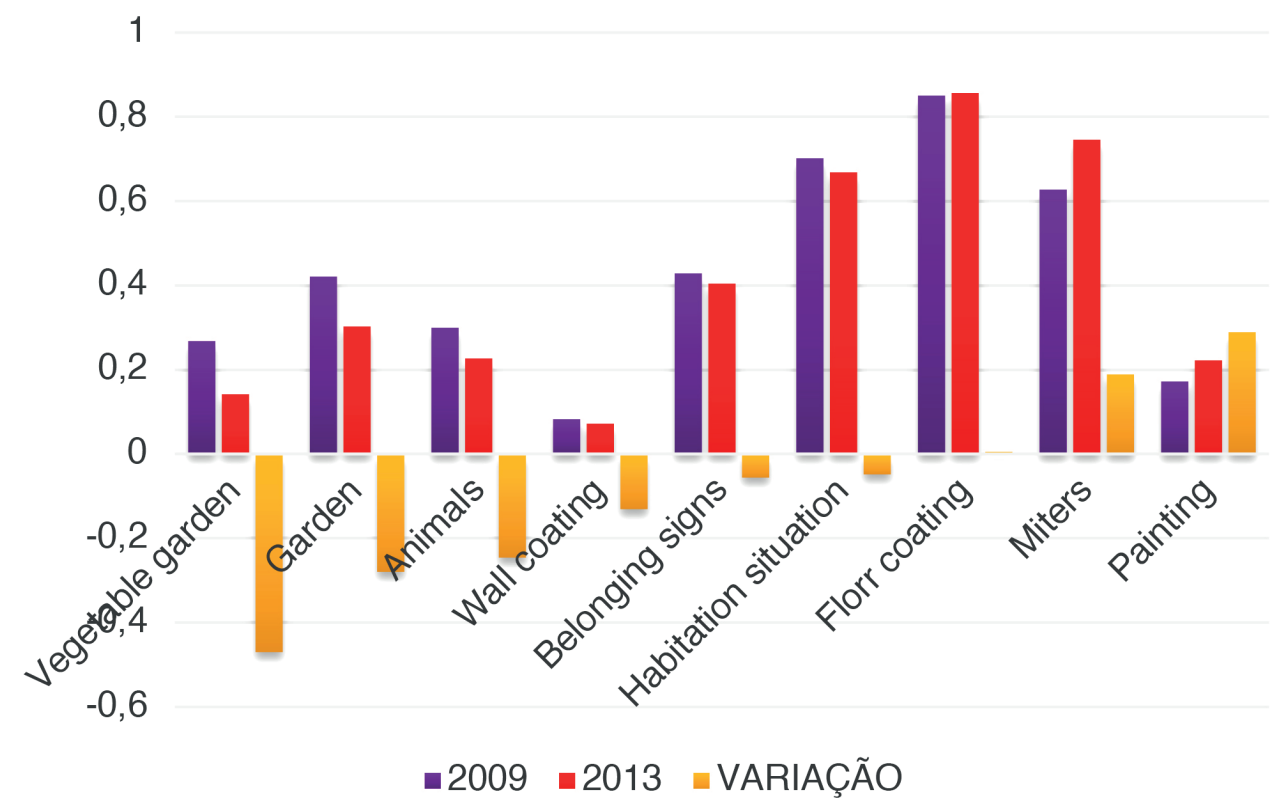

Source: Elaborated by the authors after data collected in field research.

community is located to the left margin of the confluence between the Lake of the Tupe and the Negro River, distancing in a straight line about 40 kilometers of the Marina of the Davi, district of Compensa, Manaus. It is the point of board and land of the majority of the boats that make the route with regularity between the SDR of Tupé and the city. Bordering the river towards Manaus, there are touristic residential areas and small farms with family farming for about 8 kilometers. In this area the sand of the river, are uncovered forming beautiful beaches. The most important and frequented is the Tupe beach, located in the small area that separates the Negro River from the Tupé Lake. Over the margins of the lake there are most of the areas of family farming, in general, restricted to the cassava planting, açaí, cupuaçu, and nut collect, and, in lower scale, pupunha and tucumã palm collect. Between these areas there are the presence of many imponent touristic houses.

The Tables 3 and 4 the data indicating "belonging signs" are systematized for the constructions find in the central nucleus of the São João of Tupé Community, collected in two moments: 2009 and 20I3.

In São João of Tupé Community the belonging signs coefficient in 2009 was 0,572, which shows a situation a little bit above the median to belonging signs of the studied population. It weights negatively for the calculation, the low percentual of houses with coating in cold areas, painting, gardens, animals and vegetable garden. Reinforcing positively the number, most of the houses use floor and windows made out of wood and the house situation is fairly consolidate in terms of occupied constructions.

After four years, in the work carried out in 20I3, the situation of the riverine community of São João do Tupé, in its "belonging signs" aspect, went from significant transformation. At the end of the data ponderation, the elements that show the "belonging signs" reduced its value in $28 \%$ approximately during the study period, reaching, in 2013 , the mark of o,4Io. The following elements had a negative impact: walls coating, vegetable garden, painting, and garden; above the median there was the variables: miters, house situation, and floor coating. Examining item by item, however, it is possible to notice that some of the variables presented decayed significantly higher than the others.

The Figure 3 presents the variables disposed in function of the higher percentual decay to the lower. Variables such as farm animals, with 55, $76 \%$ of reduction; vegetable garden, with $55,42 \%$; garden, with 43,22\%; and wall coating, with $39,02 \%$, are growing indicators of deterioration in the relations with the place. This deterioration can be confirmed by the reduction in the number of occupied houses and in construction that went from 68 to 52 . However, the quantity of empty and abandoned houses is surprisingly high: from 12 in 2009 to 35 in 2013 , an increase of almost $200 \%$. 
STUDY ON THE SUSTAINABLE INDICATORS AND RESEARCH METHODOLOGY IN THE CONTEXT OF THE SUSTAINABLE DEVELOPMENT RESERVE OF TUPÉ, AMAZONAS - BRAZIL MARIOSA; DE BENEDICTO; SUGAHARA

Table 3 - Aspects of belonging signs of São João do Tupe community in the SDR of Tupé in 2009

\begin{tabular}{|c|c|c|c|c|c|c|c|c|}
\hline $\begin{array}{c}\text { Habitation } \\
\text { Situation }\end{array}$ & $\begin{array}{c}\text { In } \\
\text { Construction }\end{array}$ & Occupied & Touristic & Empty & Abandoned & $\begin{array}{c}\text { Reached } \\
\text { Points }\end{array}$ & $\begin{array}{l}\text { Possible } \\
\text { Points }\end{array}$ & Coefficient \\
\hline & 2 & 66 & IO & 3 & 9 & \multirow{3}{*}{$6 \mathrm{I} 4$} & \multirow{3}{*}{900} & \multirow{3}{*}{0,682} \\
\hline Given Weight & IO & 8 & 6 & 2 & $\mathrm{o}$ & & & \\
\hline Sub-Total & 20 & 528 & 60 & 6 & $\mathrm{o}$ & & & \\
\hline \multirow{2}{*}{$\begin{array}{c}\text { Vegetable } \\
\text { Garden }\end{array}$} & Diversified & Monoculture & Inexistent & & & $\begin{array}{c}\text { Reached } \\
\text { Points }\end{array}$ & $\begin{array}{c}\text { Possible } \\
\text { Points }\end{array}$ & Coefficient \\
\hline & $\mathrm{I} 4$ & 2 & II & & & \multirow{3}{*}{ I52 } & \multirow{3}{*}{270} & \multirow{3}{*}{0,563} \\
\hline Given Weight & IO & 6 & o & & & & & \\
\hline Sub-Total & 140 & $\mathrm{I} 2$ & $\circ$ & & & & & \\
\hline \multirow[t]{2}{*}{ Floor Coating } & $\begin{array}{c}\text { Uncovered } \\
\text { Floor }\end{array}$ & Cemented & Ceramic & Wood & Other & $\begin{array}{c}\text { Reached } \\
\text { Points }\end{array}$ & $\begin{array}{c}\text { Possible } \\
\text { Points }\end{array}$ & Coefficient \\
\hline & 2 & II & 9 & IO & I & \multirow{3}{*}{269} & \multirow{3}{*}{330} & \multirow{3}{*}{0,815} \\
\hline Given Weight & 4 & 8 & IO & 9 & 2 & & & \\
\hline Sub-Total & 8 & 88 & 90 & $8 \mathrm{I}$ & 2 & & & \\
\hline \multirow{2}{*}{$\begin{array}{c}\text { Wall } \\
\text { Covering }\end{array}$} & Excelent & Good & Medium & Regular & Inexistent & $\begin{array}{c}\text { Reached } \\
\text { Points }\end{array}$ & $\begin{array}{c}\text { Possible } \\
\text { Points }\end{array}$ & Coefficient \\
\hline & 3 & I & 3 & 2 & $\mathrm{I} 2$ & \multirow{3}{*}{64} & \multirow{3}{*}{$2 \mathrm{IO}$} & \multirow{3}{*}{0,305} \\
\hline Given Weight & IO & 8 & 6 & 4 & 0 & & & \\
\hline Sub-Total & 30 & 8 & I8 & 8 & 0 & & & \\
\hline \multirow[t]{2}{*}{ Animals } & Presence & Absence & & & & $\begin{array}{c}\text { Reached } \\
\text { Points }\end{array}$ & $\begin{array}{c}\text { Possible } \\
\text { Points }\end{array}$ & Coefficient \\
\hline & I4 & $\mathrm{I} 2$ & & & & \multirow{3}{*}{$\mathrm{I} 4 \mathrm{O}$} & \multirow{3}{*}{260} & \multirow{3}{*}{0,538} \\
\hline Given Weight & IO & 0 & & & & & & \\
\hline Sub-Total & $\mathrm{I} 4 \mathrm{O}$ & 0 & & & & & & \\
\hline \multirow[t]{2}{*}{ Wall Paint } & Excelent & Good & Medium & Regular & Inexistent & $\begin{array}{c}\text { Reached } \\
\text { Points }\end{array}$ & $\begin{array}{c}\text { Possible } \\
\text { Points }\end{array}$ & Coefficient \\
\hline & I & 2 & $\mathrm{I} 2$ & I6 & IO & \multirow{3}{*}{$\mathrm{I} 62$} & \multirow{3}{*}{$4 \mathrm{IO}$} & \multirow{3}{*}{0,395} \\
\hline Given Weight & IO & 8 & 6 & 4 & 0 & & & \\
\hline Sub-Total & IO & I6 & 72 & 64 & 0 & & & \\
\hline \multirow[t]{2}{*}{ Miter } & Glass & Wood & Aluminium & Iron & Inexistent & $\begin{array}{c}\text { Reached } \\
\text { Points }\end{array}$ & $\begin{array}{c}\text { Possible } \\
\text { Points }\end{array}$ & Coefficient \\
\hline & 5 & I6 & $\mathrm{I}$ & 2 & 2 & \multirow{3}{*}{ I98 } & \multirow{3}{*}{260} & \multirow{3}{*}{0,762} \\
\hline Given Weight & IO & 8 & 8 & 6 & o & & & \\
\hline Sub-Total & 50 & $\mathrm{I} 28$ & 8 & $\mathrm{I} 2$ & 0 & & & \\
\hline \multirow[t]{2}{*}{ Garden } & Plant Beds & Lawn & Vases & Trees & Inexistent & $\begin{array}{c}\text { Reached } \\
\text { Points }\end{array}$ & $\begin{array}{c}\text { Possible } \\
\text { Points }\end{array}$ & Coefficient \\
\hline & IO & 2 & 8 & 8 & IO & \multirow{3}{*}{ I96 } & & \\
\hline Given Weight & IO & 8 & 6 & 4 & 0 & & 380 & $0,5^{16}$ \\
\hline Sub-Total & 100 & I6 & 48 & 32 & o & & & \\
\hline
\end{tabular}

IQSA RESIDENCES - BELONGING SIGNS - PONDERATION O TO I TO THE REACHED POINT AND THE POSSIBLE

POINTS TO EACH ONE OF O8 CONSIDERED VARIABLES - NOT INFORMED WERE DISCARDED 
Table 4-Aspects of Belonging Signs of São João do Tupé community in 2013

\begin{tabular}{|c|c|c|c|c|c|c|c|c|}
\hline Habitation & $\begin{array}{c}\text { In } \\
\text { Construction }\end{array}$ & Occupied & Touristic & Empty & Abandoned & $\begin{array}{l}\text { Reached } \\
\text { Points }\end{array}$ & $\begin{array}{l}\text { Possible } \\
\text { Points }\end{array}$ & Coefficient \\
\hline & 8 & 44 & I5 & 20 & I5 & \multirow{3}{*}{562} & \multirow{3}{*}{ IO2O } & \multirow{3}{*}{$0,55^{\mathrm{I}}$} \\
\hline Given Weight & IO & 8 & 6 & 2 & o & & & \\
\hline Sub-Total & 80 & $35^{2}$ & 90 & 40 & o & & & \\
\hline \multirow{2}{*}{$\begin{array}{l}\text { Vegetable } \\
\text { Garden }\end{array}$} & Diversified & Monoculture & Inexistent & & & $\begin{array}{l}\text { Reached } \\
\text { Points }\end{array}$ & $\begin{array}{c}\text { Possible } \\
\text { Points }\end{array}$ & Coefficient \\
\hline & $2 \mathrm{I}$ & 3 & 67 & & & \multirow{3}{*}{228} & \multirow{3}{*}{ 910 } & \multirow{3}{*}{$0,25 \mathrm{I}$} \\
\hline Given Weight & IO & 6 & o & & & & & \\
\hline Sub-Total & 210 & I8 & ० & & & & & \\
\hline \multirow[t]{2}{*}{ Floor Coating } & $\begin{array}{c}\text { Uncovered } \\
\text { Floor } \\
\end{array}$ & Cemented & Ceramic & Wood & Other & $\begin{array}{l}\text { Reached } \\
\text { Points }\end{array}$ & $\begin{array}{l}\text { Possible } \\
\text { Points }\end{array}$ & Coefficient \\
\hline & II & 44 & $\mathrm{I} 2$ & 24 & 2 & \multirow{3}{*}{736} & \multirow{3}{*}{930} & \multirow{3}{*}{0,791} \\
\hline Given Weight & 4 & 8 & IO & 9 & 2 & & & \\
\hline Sub-Total & 44 & $35^{2}$ & $\mathrm{I} 2 \mathrm{O}$ & 216 & 4 & & & \\
\hline \multirow{2}{*}{$\begin{array}{c}\text { Wall } \\
\text { Covering }\end{array}$} & Excelent & Good & Medium & Regular & Inexistent & $\begin{array}{l}\text { Reached } \\
\text { Points }\end{array}$ & $\begin{array}{c}\text { Possible } \\
\text { Points }\end{array}$ & Coefficient \\
\hline & 6 & 8 & 3 & 5 & 65 & \multirow{3}{*}{ I62 } & \multirow{3}{*}{870} & \multirow{3}{*}{ o, I86 } \\
\hline Given Weight & IO & 8 & 6 & 4 & o & & & \\
\hline Sub-Total & 60 & 64 & I8 & 20 & o & & & \\
\hline \multirow[t]{2}{*}{ Animals } & Presence & Absence & & & & $\begin{array}{c}\text { Reached } \\
\text { Points }\end{array}$ & $\begin{array}{c}\text { Possible } \\
\text { Points }\end{array}$ & Coefficient \\
\hline & 20 & 64 & & & & \multirow{3}{*}{200} & \multirow{3}{*}{840} & \multirow{3}{*}{0,238} \\
\hline Given Weight & IO & o & & & & & & \\
\hline Sub-Total & 200 & o & & & & & & \\
\hline \multirow[t]{2}{*}{ Wall Paint } & Excelent & Good & Medium & Regular & Inexistent & $\begin{array}{l}\text { Reached } \\
\text { Points }\end{array}$ & $\begin{array}{c}\text { Possible } \\
\text { Points }\end{array}$ & Coefficient \\
\hline & 6 & $\mathrm{I} 2$ & 8 & I7 & $5^{2}$ & \multirow{3}{*}{272} & \multirow{3}{*}{950} & \multirow{3}{*}{0,286} \\
\hline Given Weight & IO & 8 & 6 & 4 & o & & & \\
\hline Sub-Total & 60 & 96 & 48 & 68 & o & & & \\
\hline \multirow[t]{2}{*}{ Miter } & Glass & Wood & Aluminium & Iron & Inexistent & $\begin{array}{c}\text { Reached } \\
\text { Points }\end{array}$ & $\begin{array}{c}\text { Possible } \\
\text { Points }\end{array}$ & Coefficient \\
\hline & 9 & 69 & 2 & 6 & $\mathrm{I} 2$ & \multirow{3}{*}{670} & \multirow{3}{*}{980} & \multirow{3}{*}{0,684} \\
\hline Given Weight & IO & 8 & 8 & 6 & o & & & \\
\hline Sub-Total & 90 & $55^{2}$ & I6 & $\mathrm{I} 2$ & o & & & \\
\hline \multirow[t]{2}{*}{ Garden } & Plant Beds & Lawn & Vases & Trees & Inexistent & $\begin{array}{l}\text { Reached } \\
\text { Points }\end{array}$ & $\begin{array}{l}\text { Possible } \\
\text { Points }\end{array}$ & Coefficient \\
\hline & 8 & $\mathrm{I} 3$ & 6 & II & $5^{2}$ & \multirow{3}{*}{264} & & \\
\hline Given Weight & IO & 8 & 6 & 4 & o & & 900 & 0,293 \\
\hline Sub-Total & 80 & IO4 & 36 & 44 & ० & & & \\
\hline
\end{tabular}

IQSA RESIDENCES - BELONGING SIGNS - PONDERATION O TO I TO THE REACHED POINT AND THE POSSIBLE POINTS TO EACH ONE OF O8 CONSIDERED VARIABLES - NOT INFORMED WERE DISCARDED 


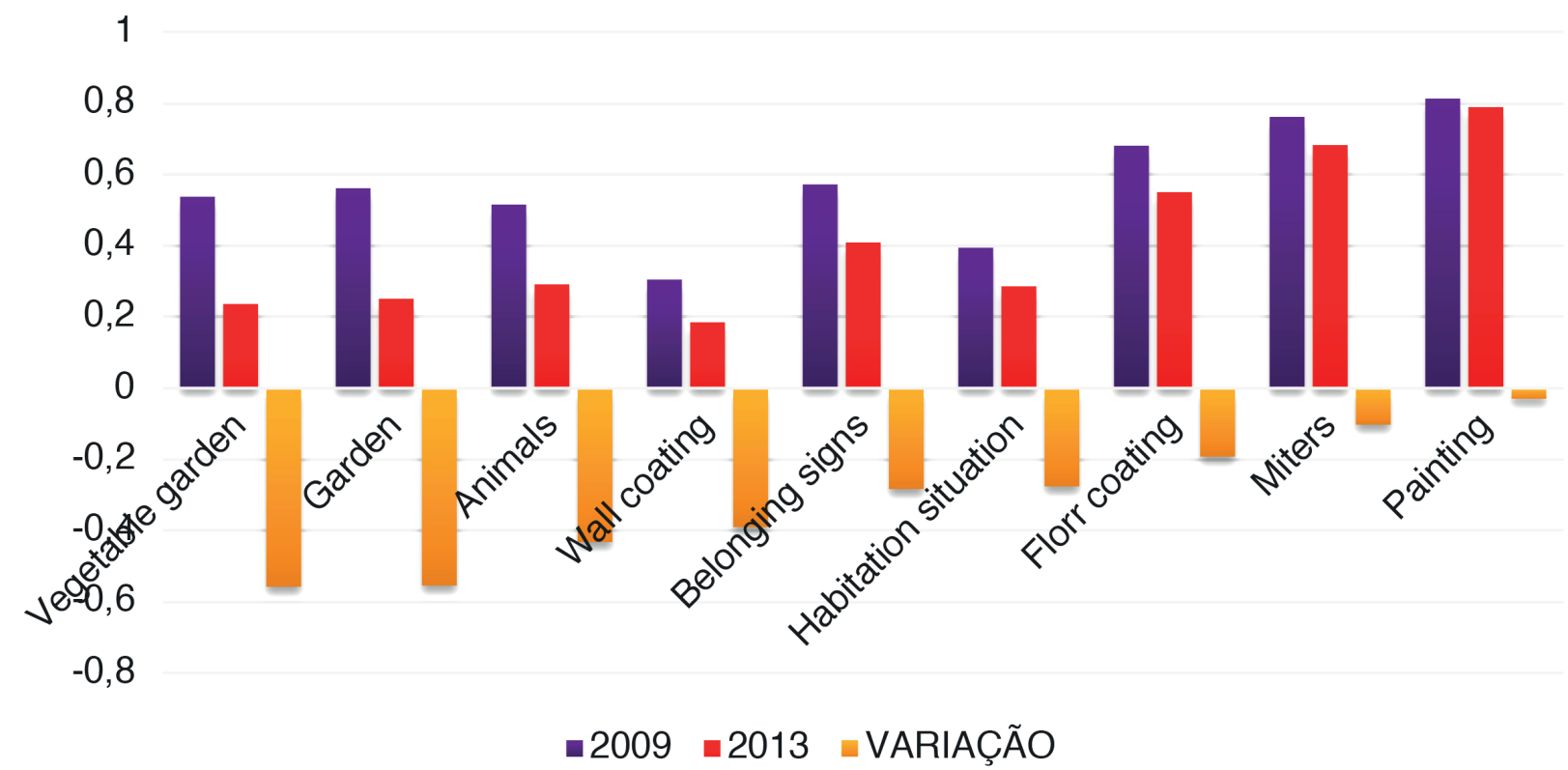

Source: Elaborated by the authors after data collected in field research.

5.4 IMPACTS OF INCOME AND WORK DYNAMIC

The studied riverine communities, São João of Tupé and Agrovila, although under the same regulations, limits and directions of the activities in their interior, determined by the environmental legislation - in special the Law 9.985 (Brasil, 20II), where in its Article 20 stablishes the characteristics of the Units classified as "Sustainable Development Reserve", do not follow the same demographic trajectory.

This way, the work conditions, social interactions, and norms of convivence highlighted on the chart 3 presented peculiarities that lead to social-spatial vulnerability. While in São João of Tupe there is an emptying of the habitation units around 23,5\%; at Agrovila this flow was positive in $24 \%$, in the same period. This reality can be explained with the economic indicators used in this study: work (main occupation) and main income of the residents, for the two Communities and in two successive moments of the data collection in 2010 and 2014.

For the calculation of the percentual there were disregard the answers where the informants did not know or did not want to answer. In the first data collection, accomplished in 20I0, Iоo residents were interviewed in São João of Tupé community and 88 residents in Agrovila community. In 20I4, the interviewed number were, respectively, Io3 and 163 .
Table 5 shows that in 2010 the activities linked to agriculture used to occupy the same percentage of residents in both Communities: $17,34 \%$ in São João of Tupé and $18,75 \%$ in Agrovila. The commerce, on the other hand, presented the percentage of twice of the number of residents in São João of Tupé (IO,2I\%) in comparison to Agrovila (5,00\%). Regarding the main occupation income, $42,56 \%$ of the residents of São João of Tupé community declared that they receive up to 4 minimum wages; while in Agrovila community, the percentage was a little bit lower: $39, \mathrm{r} 9 \%$.

In 20I4, however, the variable connected to the economic indicators described a different reality (Table 6). The activities linked to agriculture, that occupied $17,34 \%$ from the residents of São João of Tupé in 20ro, decayed to $1,37 \%$ in 20I4. Nonetheless, in Agrovila Community, the percentage did not present a big variation: from $18,75 \%$ in 2010 , to $17,24 \%$ in 2014 . Regarding the percentage of commerce, the reduction was noticed in both communities, but, representing a bigger impact in São João of Tupé community. This one, that in 2010 presented a percentage of IO,2I\% of residents which the main occupation was commerce, decayed to 4,II\% in 20I4. In Agrovila there was also a reduction, but not so big: from $5 \%$ declared in 2010 , the percentage changed to 3,44 in 20I4. From the analyzed data, the income reduction is, from the explanatory point of view to the variations in the "belonging signs", perhaps the most important. While, in 2010, in São João 
Table 5 - Percentage distribution of occupation and main income of the residents of São João of Tupé and Agrovila Communities in 2010

\begin{tabular}{|c|c|c|c|c|c|c|}
\hline $\begin{array}{c}\text { MAIN } \\
\text { OCCUPATION }\end{array}$ & $\begin{array}{l}\text { PUBLIC AGENTS } \\
\text { AND RETIRED }\end{array}$ & FORMAL JOB & AGRICULTURE & COMMERCE & EVENTUAL JOB & $\begin{array}{c}\text { STUDENT, } \\
\text { MINOR, AND } \\
\text { NOT INFORMED }\end{array}$ \\
\hline São João do Tupé & $7, \mathrm{I} 4$ & IO,2I & $\mathrm{I} 7,34$ & IO,2I & 0,00 & $55, \mathrm{IO}$ \\
\hline Agrovila & IO,OO & IO,OO & $\mathrm{I} 8,75$ & 5,00 & ০,০০ & 56,25 \\
\hline MAIN INCOME & OVER O4 MW & $\begin{array}{c}\text { FROM O3 TO } \\
\text { O4 MW }\end{array}$ & $\begin{array}{c}\text { FROM O2 TO } \\
\text { O3 MW }\end{array}$ & $\mathrm{DE}$ OI A $02 \mathrm{SM}$ & UP TO OI MW & NO INCOME \\
\hline São João do Tupé & ০,০০ & $2, \mathrm{I} 2$ & $2, \mathrm{I} 2$ & 4,25 & 34,04 & 57,47 \\
\hline Agrovila & 0,00 & $\mathrm{I}, 35$ & 0,00 & 4,05 & 33,78 & 60,82 \\
\hline
\end{tabular}

Source: Elaborated by the authors, from data collected in São João of Tupé and Agrovila Communities.

Table 6 - Percentage distribution of occupation and main income of the residents of São João of Tupé and Agrovila Communities in 2014

\begin{tabular}{|c|c|c|c|c|c|c|}
\hline $\begin{array}{c}\text { MAIN } \\
\text { OCCUPATION }\end{array}$ & $\begin{array}{l}\text { PUBLIC AGENTS } \\
\text { AND RETIRED }\end{array}$ & FORMAL JOB & AGRICULTURE & COMMERCE & EVENTUAL JOB & $\begin{array}{c}\text { STUDENT, } \\
\text { MINOR, AND } \\
\text { NOT INFORMED }\end{array}$ \\
\hline São João do Tupé & I0,95 & I0,95 & $\mathrm{I}, 37$ & $4, \mathrm{II}$ & ০,০০ & 72,62 \\
\hline Agrovila & 6,03 & IO,34 & I7, 24 & 3,44 & 3,44 & $59,5 \mathrm{I}$ \\
\hline MAIN INCOME & OVER O4 MW & $\begin{array}{c}\text { FROM O3 TO } \\
\text { O4 MW }\end{array}$ & $\begin{array}{c}\text { FROM O2 TO } \\
\text { O3 MW }\end{array}$ & DE OI A O2 SM & UP TO OI MW & NO INCOME \\
\hline São João do Tupé & ০,০০ & ০,০০ & ০,০০ & $\mathrm{I} 2,25$ & II,II & 76,64 \\
\hline Agrovila & ০,০০ & 0,93 & 3,73 & 3,73 & 26,16 & 65,45 \\
\hline
\end{tabular}

Source: Elaborated by the authors, from data collected in São João of Tupé and Agrovila Communities.

of Tupé $42,56 \%$ of the residents declared to have a source of income; in 20I4 this number was reduced to $23,62 \%$. In Agrovila Community, the reduction was lower: from the $39,19 \%$ in 2010 , to $34,58 \%$ in 20I4, but compensated by the amount received. The percentage of informants with income above 02 minimum wages increase from $\mathrm{I}, 35 \%$ in 2010 to $4,66 \%$ in 2014 . In São João of Tupé community the opposite occurred. While, in 2010, the percentage of residents with a declared income of 02 minimum wages was $4,24 \%$, in 2014 the number was reduced to $0,00 \%$.

The tendency of populational dislocation, characterized by the lower number of actual residents in the community of São João of Tupé, can be proved by the absence of a higher dynamic in the local commerce. If, in 2010, $10,21 \%$ of the population were involved with commerce, in 2014 this number decreased to $4, \mathrm{Ir} \%$. When, in 2018 , interviews were conducted with the residents of the community that has some kind of independent 464 despite being formalized or not, the demographic depletion was consolidated. Only i2 local economic enterprises were finding, involving activities of basic items trade and, tourist-oriented activities, that come to the local specially on the weekends and holydays, being closed during the other days.

\section{CONCLUSION}

The present study proposed some sustainability indicators (and their respective variables) and looked for validate a research methodology that could be used to study the belonging of people living in Sustainable Development Reserves. Therefore, the considerations outlined below apply and are even restricted to the context in which the data were collected and the concrete situations exposed in this study.

The analysis of the set of dimensions, indicators, and variables (environmental, spatial, cultural, social, and economic) used for the belonging signs of the studied communities in 
distinct moments, suggest a correspondence or concomitance between the found values and the populational dislocation tendency. There were excluded from the analysis the touristic houses, public buildings or for collective use, or the habitations used for temporary purposes or to any other reason but a stabilized living. It was observed that, in the locals where the belonging signs variables presented a reduced value, the demographic data showed a decay in the number of houses used for living in the next period. In the same way, at that local where the variables that characterizes the belonging signs, reached a higher value or maintained itself, the demographic profile presented a tendency of reception or permeance of residents in the second moment of the research.

A situation in special was considered to explain this phenomenon: the existence of a restrictive environmental legislation reproducing limited conditions to income and work. The social variable "respect to norms and laws" for coexistence seems to influence the configuration of the demographic profile of the studied regions.

The communities compared - São João of Tupé and Agrovila - are located in a Sustainable Development Reserve, being under the environmental legislation determinations. The land use and occupation, agricultural activities, extractive or commercial use of flora and fauna specimen, and the ones that potentialize touristic activities are regulated, inspected, and controled by mechanisms, sectors, and public agents, linked to environmental secretarys. This suggests that for the economic dynamics, their boundaries and potentialities, it is necessary to consider first the environmental preservation, above the communities' interests.

According to the residents testimonies, the agents of SEMMAS (Municipal Secretariat of Environment and Sustainability, Manaus, AM), in charge of inspection of the activities inside the SDR of Tupé, prohibit planting, hunting, fishing, and forest goods collecting that, according to the residents, are part of the culture and secular practices of which they are used to. Until now there is no public politics alternative to help the resident's subsistence. Because of that, the indicator "work, income, and job conditions" present in both communities has an impact in the desire of populational dislocation. It is due to the lack of adequate conditions, to the exercise of productive activities or to obtaining income in adequate amounts and in a continuous flow, that the residents of the Community of São João of Tupé leave it. From them, some prefer to live in Agrovila Community; other ones are attracted to the other communities or simply move back to Manaus urban area.

It is observed, however, that the deterioration of the permanence conditions at a given area it is a process. Opposing to the objective condition of life and existence that deteriorates over the time, remain the socio-cultural bonds, psychosocial links and biographies historic linked to the local, weighing individual decisions to leave or stay. To finish, in this context, it is highlighted the importance of indicators related to the environmental, spatial, cultural, social and economic dimensions inherent to sustainability conditions as elements strongly influenced by the degree of resilience of the subjects, in this study scaled by the degree of belonging and materialized in the "belonging signs".

Finally, it is emphasized that this is a complex subject that still reveals many complex and even contradictory aspects, necessitating, therefore, other accurate and contextualized reflections. This way, the authors recognize that the considerations being presented here only touch the "tip of the iceberg", not depleting the subject. Further studies are needed with the depth and perspicacity that the theme deserves.

\section{REFERENCES}

Almeida, L. Q. (2011) Por uma ciência dos riscos e vulnerabilidades na geografia. Mercator, 10(23), 83-99,126.

Almeida, M. G., Vargas, M. A. M., \& Mendes, G. F. (2011) Territórios, paisagens e representações: um diálogo em construção. Mercator, 10(22), 23-35.

Amaral, S. et al. (2013) Comunidades ribeirinhas como forma socioespacial de expressão urbana na Amazônia: uma tipologia para a região do Baixo Tapajós (Pará-Brasil). Revista Brasileira de Estudos de População, 30(2), 367-399.

Araújo, F. A. V., \& Soares, B. R. (2009) Relação cidadecampo: desafios e perspectivas. Campo-Território: Revista de Geografia Agrária, 4(7), 201-229.

Araújo, R., Fernandes, V., \& Rauen, W. (2015) Indicadores de sustentabilidade no contexto do design de produtos. Revista de Gestão dos Países de Língua Portuguesa, 14(2), 14-27.

Bauman, Z. (2012) Ensaios sobre o conceito de cultura. Rio de Janeiro: Zahar.

Bellen, H. M. (2002) Indicadores de sustentabilidade: uma análise comparativa. Tese de Doutorado, Universidade Federal de Santa Catarina, Florianópolis, SC, Brasil. 
Bellen, H. M. Indicadores de sustentabilidade: uma análise comparativa. 2. ed. Rio de Janeiro: FGV, 2008.

Gomes, M. F. V. B. (2010) Desigualdade socioambiental no espaco urbano de guarapuava.(Report). Ra'eGa, 20(1), p. 95105.

Brasil. Ministério do Meio Ambiente. (2011) SNUC - Sistema Nacional de Unidades de Conservação da Natureza: Lei ${ }^{\circ}$ 9.985, de 18 de julho de 2000. Brasília: MMA/SBF.

Brito, F., \&; Souza, J. (2005) Expansão urbana nas grandes metrópoles: o significado das migrações intrametropolitanas e da mobilidade pendular na reprodução da pobreza. São Paulo em Perspectiva, 19(4), 48-63.

Carvalho, M. T. M., \& Sposto, R. M. (2012) Metodologia para avaliação da sustentabilidade de habitações de interesse social com foco no projeto. Ambiente Construído, 12(1), 207-225.

Cebrap. (2016) Métodos de Pesquisa em Ciências Sociais. São Paulo: Sesc-Cebrap.

Challinor, E. P. (2011) Identidade e pertença: para além das dimensões materiais do sofrimento social. Etnográfica, 15(3). 479-500.

Chizzotti, A. (2005) Pesquisa em ciências humanas e sociais. 7. ed. São Paulo: Cortez.

Daly, H. E., \& Cobb Junior, J. B. (1994) For the Common Good. Redirecting the economy toward community, the environment, and a sustainable future. Boston, MA: Beacon Press.

Donnelly, A., Jones, M., O’Mahony, T., \& Byrne, G. (2007) Selecting environmental indicator for use in strategic environmental assessment. Environmental Impact Assessment Review, 27(2), 161-175.

Duarte, P. (2011) Esquadrias e vidros na construção civil. Revista Vidro Impresso, 5(1) 74-75.

Elias, N. (1994) A sociedade dos indivíduos. Rio de Janeiro: Zahar.

Fahy,F.,\&Rau,H.(2013)Methods of sustainability research in the social sciences. London: Sage.

Fausto, B. (1999) Fazer a América: a imigração em massa para a América Latina. São Paulo: Edusp.

Fang, K., Heijungs, R., \& De Snoo, G. R. (2014) Theoretical exploration for the combination of the ecological, energy, carbon, and water footprints. Ecological Indicators, 36(1), 508-518.

Geertz, C. (2001) O saber local: novos ensaios em antropologia interpretativa. Petropolis: Vozes.

Giddens, A. (2009) A constituição da sociedade. São Paulo: Martins Fontes.

Gil, A. C. (2019) Métodos e técnicas de pesquisa social. 7. ed. São Paulo: Atlas.

Guimarães, R. P., \& Feichas, S. A. Q. (2009) Desafios na construção de indicadores de sustentabilidade. Ambiente \& sociedade, 12(2), 307-323.

Haesbaert, R. (2007) Território e multiterritorialidade: um debate. GEOgraphia, 9(17), 19-45.

Ingold, T. (2000) The perception of the environment: essays on livelihood, dwelling and skill. New York: Psychology Press.
Ingold, T. (2012) Trazendo as coisas de volta à vida: emaranhados criativos num mundo de materiais. Horizontes antropológicos, 18(37), 25-44.

Jannuzzi, P. M. (2016) Monitoramento e avaliação de programas sociais: uma introdução aos conceitos e técnicas. Campinas - SP: Alínea.

Kovalski, R. A. (2016) Desenvolvimento territorial sustentável: uma análise da evolução do pensamento humano em relação à consciência sobre o meio ambiente. Revista de Humanidades, 31(1), 101-120.

Leff, E. (2009) Ecologia, capital e cultura: a territorializaçao da racionalidade ambiental. Petrópolis, RJ: Vozes.

Lawn, P. (Ed.). (2006) Sustainable Development Indicators in Ecological Economics. Cheltenham, UK: Edward Elgar.

Lozano, R. (2008) Envisioning sustainability threedimensionally. Journal of Cleaner Production, 16(17), 1838-1846.

Marchand, G. A. (2014) Avaliação da gestão da fauna silvestre na comunidade de São João do Tupé (Manaus, Amazonas) pelo meio de um sistema de indicadores. Confins. Revue franco-brésilienne de géographie/Revista franco-brasilera de geografia, 20(1), 1-28.

Mariosa, D. F., Silva, E. N. S., Gasparini, G, \& Reis Júnior, a. M. (2014) Ribeirinhos do Rio Negro: um estudo da qualidade socioambiental. 1. ed. Curitiba: Editora CRV.

May, V. (2011) Self, belonging and social change. Sociology, 45(3), 363-378.

Medronho, R. A. (2009) Estudos Ecológicos. In: Medronho R. A. et al. (Eds.). Epidemiologia. 2. ed. São Paulo: Atheneu. 265-274.

Morgenstern, H. (1995) Ecologic Studies in Epidemiology: Concepts, Principles, and Methods. Annual Review of Public Health, 16, 61-81.

Nordhaus, W. D., \& Tobin, J. (1972) Is growth obsolete? In: Nordhaus, W. D., \& Tobin, J. Economic Research: Retrospect and Prospect. New York: NBER. v.5. p.1-80.

Ocde. (2002) Rumo a um desvolvimento sustentável: indicadores ambientais. Salvador: Centro de Recursos Ambientais.

Oliveira, C. O., Francisco, A. C., \& Goes, P. B. (2013, ) Sustentabilidade: uma visão das metodologias de avaliação. Anais do Encontro Nacional de Engenharia de Produção, Salvador, BA, Brasil, 33.

Petrie, J., Cohen, B., \& Stewart, M. (2007) Decision support frameworks and metrics for sustainable development of minerals and metals. Clean Techn Environ Policy, 9:133-145.

Pintérd, L., Hardib, P., Martinuzzic, A., \& Halla, J. (2012) Bellagio STAMP: Principles for sustainability assessment and measurement. Ecological Indicators, 17(1), 20-28.

Reis, M. N. (2011) Esquadrias de alumínio: análise dos critérios de escolha destes componentes em edifícios de apartamentos, padrão médio-alto, na Cidade de São Paulo. Tese de Doutorado, Universidade de São Paulo, São Paulo, SP, Brasil.

Richardson, R. J. (2017) Pesquisa Social: Métodos e Técnicas. 4. ed. São Paulo: Atlas.

Ridoutt, B. G., \& Pfister, S. (2013) Towards an Integrated Family of Footprint Indicators. Journal of Industrial Ecology, 17(3), 337-339. 
Santos-Silva, E. N., Scudeller, V. V., \& Cavalcanti, M. J. (EDS.). (2011) BioTupé: meio físico, diversidade biológica e sociocultural do baixo Rio Negro, Amazônia Central. v. 3. Manuas, AM: Rizoma Editorial.

Sachs, I. (2008) Desenvolvimento includente, sustentável e sustentado. Rio de Janeiro: Garamond.

Scandar Neto, W. J. (2006) Síntese que organiza o olhar: uma proposta para construção e representação de indicadores de desenvolvimento sustentável e sua aplicação para os municípios fluminenses. Dissertação de Mestrado, Escola Nacional de Ciências Estatísticas, Rio de Janeiro, RJ, Brasil.

Schlapfer, M. et al. (2014) The scaling of human interactions with city size. Journal of The Royal Society Interface, 11(98), 1-14.

Silva, E. A., Freire, O. B. L., \& Silva, F. Q. P. O. (2014) Indicadores de sustentabilidade como instrumentos de gestão: uma análise da GRI, Ethos e ISE. Revista de Gestão Ambiental e Sustentabilidade - GeAS, 3(1), 130-148.

Silva, A. W. L., Selig, P. M., \& Morales, A. B. T. (2012) Indicadores de sustentabilidade em processos de avaliação ambiental estratégica. Ambiente \& Sociedade, 15(3), 75-96.

Simões, A., Alkmin, A. C., \& Santos, C. (2017) Passado, presente e futuro da produção e análise de indicadores sociais no IBGE. In: Simões, A., \& Alkmin, A. C. (Eds.) Indicadores sociais: passado, presente e futuro. Rio de Janeiro: IBGE. p. 17-27.

Siqueira, M. M., \& Padovam, V. A. R. (2008) Bases teóricas de bem-estar subjetivo, bem-estar psicológico e bem-estar no trabalho. Psicologia: teoria e pesquisa, 24(2), 201-209.

Sobral, A.,\&Freitas, C.M.(2010) Modelo de organização de indicadores para operacionalização dos determinantes socioambientais da saúde. Saúde e Sociedade, 19(1), 35-47.

Souza, C. C. V. (2010) Etnobotânica de quintais em três comunidades ribeirinhas na Amazônia Central, Manaus - AM. Dissertação de Mestrado, Instituto Nacional de Pesquisa da Amazônia/Universidade Federal do Amazonas, AM, Brasil.

Unece/Oecd/Eurostat. (2008) Report on measuring sustainable development: statistics for sustainable development, commonalities between current practice and theory. Recuperado em 12 maio, 2019, de https://www.oecd. org/greengrowth/41414440.pdf

Veiga, J. E. (2009) Indicadores socioambientais: evolução e perspectivas. Revista de Economia Política, 29(4), 421-435.

Veiga, J. E. (2010) Indicadores de sustentabilidade. Estudos avançados, 24 (68), 39-52.

Viegas, S. F. S. S. (2014) Sustentabilidade em instituições de ensino superior: um estudo na Universidade Federal Rural da Amazônia. Dissertação de Mestrado, Universidade da Amazônia, Belém, PA, Brasil. 